\title{
Statutory Interpretation as Practical Reasoning
}

\author{
William N. Eskridge, Jr.* \\ Philip P. Frickey**
}

In the last decade, statutory interpretation has reemerged as an important topic of academic theory and discussion. ${ }^{1}$ This development is welcome, since few topics are more relevant to legal craft and education than the interpretation of statutes, now our primary source of law. The recent theoretical views, however, contrast with practicing lawyers' strategies of statutory interpretation. When practitioners give advice to clients about what a statute means, their approach is usually eclectic: They look at the text of the relevant statutory provisions, any legislative history that is available, the context in which the legislation was enacted, the overall legal landscape, and the lessons of common sense and good policy. But when law professors talk about statutory interpretation, they tend to posit a more abstract, "grand" theory that privileges one or another of these approaches as "foundational." 2 The commentators' grand theories contrast with the more ad hoc, factbased reasoning of the practicing lawyer.

How do judges interpret statutes? How should they? Many commentators argue that judicial interpretation is, or at least ought to be, inspired by grand theory. We think these commentators are wrong, both descriptively and normatively: Judges' approaches to statutory interpretation are generally eclectic, not inspired by any grand theory,

* Associate Professor of Law, Georgetown University Law Center.

** Professor of Law, University of Minnesota Law School.

We thank Daniel Farber, Dennis Patterson, Richard Posner, Suzanna Sherry, and Peter Strauss for helpful comments on an earlier draft of this article. An earlier draft of this article was presented to a faculty workshop at the Georgetown University Law Center, and we appreciate the questions and comments made there.

1. See William N. Eskridge, Jr. \& Phil.ip P. Frickey, Cases and Materials on Legislation: Statutes and the Creation of Public Policy 569-635 (1988), for an exposition and critique of the leading theories of statutory interpretation.

2. By "foundational" approach, we mean a theory that identifies a single primary legitimate source of interpretation-for example, the statutory text or legislative intent-and adheres to the statutory meaning that source suggests, regardless of the circumstances or consequences. The idea is related to, but is not the same as, philosophical "foundationalism," which argues that epistemology can provide a single analytical foundation for formulating unassailably certain beliefs. See, e.g., Anti-foundationalism and Practical Reasoning: Conversations between Hermeneutics and Analysis (E. Simpson ed. 1987); Richard Rorty, Philosophy and the Mirror of Nature (1979). 
and this is a good methodology. Stated another way, we argue that foundationalism is a flawed strategy for theorizing about statutory interpretation and that a more modest approach, grounded upon "practical reason," 3 is both more natural and more useful.

Our argument proceeds in three parts. Using three noteworthy Supreme Court cases as examples, Part I argues that the three main unitary theories of statutory interpretation-emphasizing legislative intent, purpose, and text-all fail to establish an overriding and "objective" foundation for interpreting statutes. These theories share several common weaknesses. First, each rests upon questionable premises about the nature of interpretation and the legislative process. Second, none can systematically produce determinate results in the "hard cases," which undermines their claims to "objectivity." Third, although each theory rests upon and subserves important values that should be considered when interpreting statutes, no theory persuades us that its cluster of underlying values is so important as to exclude all others. An overall difficulty of grand theory is its emphasis on the universal over the particular, its failure to recognize that statutory interpretation will work in different ways in different concrete cases.

Given the difficulties of the grand theories, one might be tempted to abandon theory entirely, and relegate statutory interpretation to pure ad hocism. This is not the approach we urge, because we find an underlying coherence in the Supreme Court's practices of statutory interpretation. In Part II, we suggest a paradigm describing the structure of practical reasoning by which the Court interprets statutes in concrete cases. According to this model, the Court considers a broad range of textual, historical, and evolutive evidence when it interprets statutes. In the easy cases, most of the evidence points in the same direction and

3. By "practical reason," we mean an approach that eschews objectivist theories in favor of a mixture of inductive and deductive reasoning (similar to the practice of the common law), seeking contextual justification for the best legal answer among the potential alternatives. For a more extended explanation, see text accompanying notes 94-150 infra; Daniel A. Farber \& Philip P. Frickey, Practical Reason and the First Amendment, 34 UCLA L. Rev. 1615, 1645-56 (1987) [hereinafter Farber \& Frickey, Practical Reason]; Richard A. Posner, The Jurisprudence of Skepticism, 86 Mich. L. Rev. 827, 837-58 (1988) [hereinafter Posner, Skepticism]; see also Daniel A. Farber, Legal Pragmatism and the Constitution, 72 MinN. L. Rev. 1331, 1341-49 (1988).

Some of the recent literature about statutory interpretation is moving away from unitary approaches toward more eclectic ones. See, e.g., William N. Eskridge, Jr., Dynamic Statutony Interpretation, 135 U. PA. L. REv. 1479 (1987) (attacking the view that statutory interpretation is always a search for original legislative intent or purpose); Daniel A. Farber \& Philip P. Frickey, Legislative Intent and Public Choice, 74 VA. L. Rev. 423 (1988) (attacking the view that statutory interpretation must focus only on the statutory text) [hereinafter Farber \& Frickey, Legislative Intent ]; William D. Popkin, The Collaborative Model of Statutony Interpretation, 61 S. CAL. L. REv. 541 (1988); Richard A. Posner, Legal Formalism, Legal Realism, and the Interpretation of Statutes and the Constitution, 37 CASE W. REs. L. REv. 179 (1986-87) [hereinafter Posner, Legal Formalism]. Our project obviously parallels recent thinking in constitutional law that questions the foundationalist strategy. See, e.g., Ronald A. Cass, The Perils of Positive Thinking: Constilutional Interprelation and Negative First Amendment Theory, 34 UCLA L. Rev. 1405 (1987); Farber, supra; Farber \& Frickey, Practical Reason, supra; Steven Shiffrin, The First Amendment and Economic Regitlation: Away from a General Theory of the First Amendment, 78 Nw. U.L. REv. 1212 (1983). 
is thereby mutually reinforcing. In the hard cases, however, the evidence points in different directions, and the Court critically analyzes each textual or historical or evolutive argument, both as to its own cogency and as to its cogency in light of the other evidence. Is the text clear on its face? Am I sure about that interpretation in light of Congress's historical expectations? Does the text shed light on those expectations, perhaps by suggesting that certain speeches on the floor of Congress did not represent prevailing attitudes? And so on. We seek to capture much of this analysis through a schematic model of practical reasoning, which seems to describe what the Court actually does when it interprets a statute.

The philosophical inspiration for our model is Aristotle's theory of practical reasoning (phronesis). Aristotle's practical philosophy starts with the proposition that one can determine what is right in specific cases, even without a universal theory of what is right. ${ }^{4}$ The Aristotelian concept of phronesis has inspired a good deal of modern philosophy of meaning, including the two schools that have provided us with the inspiration and normative justifications for our model. One is the modern hermeneutics of Hans-Georg Gadamer, who replaces the traditional metaphor of interpretation, according to which a subject retrieves meaning from an object, with an interactive theory: Interpretation, Gadamer claims, is the search for common ground between interpreter and text. ${ }^{5}$ The other tradition is American pragmatism, which began with Charles Sanders Peirce's and William James's attacks on the foundationalist philosophy of Descartes and Kant, ${ }^{6}$ and which philosophers such as Richard Rorty ${ }^{7}$ and Richard Bernstein ${ }^{8}$ have continued in recent years. Both the hermeneutical and pragmatic traditions emphasize themes of Aristotelian practical reasoning-the concrete situatedness of the interpretive enterprise, which militates against overarching theories; the complexity of interpretation and argument, which recog-

4. Aristotle, Nicomachean Ethics bk. VI, chs. 5-11 (H. Rackham trans. 1962); see RoNald Beiner, Political Judgment 72-82 (1983).

5. Hans-Georg Gadamer, Philosophical Hermeneutics (D. Linge trans. 1976); HansGeorg Gadamer, The Idea of the Good in Platonic-Aristotelian Philosophy (C. Smith trans. 1986); Hans-Georg Gadamer, Truth and Method (G. Barden \& J. Cumming trans. 2d ed. 1975). Leading secondary works are Georgia WARnKe, Gadamer: Hermeneutics, TradiTION AND REASON (1987); JoEl. C. WEINSHEIMER, GadAMER's HeRMENEUTICS: A READING OF Truth and Method (1985); Francis J. Mootz, III, The Ontological Basis of Legal Hermeneutics: A Proposed . Vodel of Inquiny Based on the Itork of Gadamer, Habermas, and Ricoeur, 68 B.U.L. REv. 523 (1988). See also William N. Eskridge, Jr., Gadamer/Statutory Interpretation, 90 CouUm. L. REv. (1990) (forthcoming).

6. Charles Sanders Peirce, 5 Collected Papers (C. Hartshorne \& P. Weiss eds. 1960); Charles Sanders Peirce, Philosophical Writings of Peirce (J. Bochler ed. 1940); William James, Pragmatism: A New Name for Some Old Ways of Thinking (1907).

7. Richard Rorty, Consequences of Pragmatism (1982); R. Rorty, supra note 2.

8. Richard J. Bernstein, Beyond Objectivism and Relativism: Science, Hermeneutics, and Praxis (1983) [hereinafter R. Bernstein, Beyond Objectivism]; Richard J. BernStein, Philosophical Profiles: Essays in a Pragmatic Mode 58-114 (1986) [hereinafter R. Bernstein, Philosophical Profiles]. 
nizes that different values will pull the interpreter in different directions; and the importance of workable resolutions to complex questions. As we argue in Part II, these traditions suggest the approach we describe.

Moreover, we contend in Part III, these traditions and our model of practical reasoning offer methods and criteria for criticizing the Court's approach. In some cases, we claim, the Court distorts some of the interpretive factors or appears to ignore or minimize relevant evolutive factors, in an attempt to make the cases easier than in fact they are. In these moments, the Court seems to be gripped by a form of "countermajoritarian anxiety": As unelected judges, applying statutes enacted by our elected legislators, they feel some pressure to tie their results rigorously to the expectations that legislators had when they enacted the statute. Any result not related to majoritarian expectations may seem illegitimate in a democracy.

This anxiety, which probably explains the persistence of foundationalist theories and rhetoric among scholars and jurists, can be dispelled by persuasive arguments from the hermeneutical and pragmatic traditions. If the Court accepted these arguments, it would not only be more explicit as to the practical reasoning by which it reaches its results, but in some cases it would probably reason differently. Specifcally, it would be more likely to consider "evolutive" arguments that stress the change in circumstances between enactment and decision.

\section{The Failure of Foundationalist Theories OF STATUTORY INTERPRETATION}

Traditional theories have always considered a variety of factors relevant for statutory interpretation. ${ }^{9}$ In the post-World War II era, however, legal scholars have preferred theories that offer a unitary foundation for statutory interpretation. Much of the theoretical debate has been over which of the competing foundations is the best one. The three main theories today emphasize (1) the actual or presumed intent of the legislature enacting the statute ("intentionalism"); (2) the actual or presumed purpose of the statute ("purposivism" or "modified intentionalism"); and (3) the literal commands of the statutory text ("textualism"). ${ }^{10}$ We call these theories "foundationalist," because each seeks

9. For examples of traditional treatises that avoid grand, foundational theories of statutory interpretation, see F.A.R. BENNION, STATUTORY INTERPRETATION (1984); EARL TheOdorE Crawford, The Construction of Statutes (1940); Elmer A. Driedger, The Construction of Statutes (2d ed. 1983); Maxwell on the Interpretation of Statutes (P. Langan 12th ed. 1969); 2A Sutherland Statutory Construction (N. Singer ed., C.D. Sands 4th ed., 1985 revision). This pragmatic perspective is also exemplified by ReEd Dickerson, The INterpretation and Application of Statutes (1975); James Willard HuRst, Dealing wrth STATUTES 31-65 (1982).

10. Most of this terminology is taken from Paul Brest, The Misconceived Quest for the Original Understanding, 60 B.U.L. Rev. 204 (1980). 
an objective ground ("foundation") that will reliably guide the interpretation of all statutes in all situations.

Each of the three grand theories seeks to reconcile statutory interpretation by unelected judges with the assumptions of majoritarian political theory. Toward this end, each seeks an objective standard that will constrain the discretion of judicial interpreters. And each theory fails. In light of both modern scholarship on interpretation and concrete experience in statutory cases, all three theories suffer from flawed assumptions, indeterminacy, and nonexclusivity. To begin with, each theory posits an anchoring value-legislative "intent" or "purpose," or statutory "plain meaning"- that rests upon certain questionable assumptions. When we examine these assumptions, each anchoring idea loses its close link to majoritarian legitimacy. Moreover, upon close scrutiny the essential indeterminacy of the anchoring ideas becomes clear. Thus, legislative intent and purpose prove to be distressingly malleable, and even such "hard" evidence as statutory text turns out to be quite flexible. A grand theory loses much of its raison d'être, we argue, if it cannot reliably assure determinate results. Finally, even if its results were fully consistent with democratic principles and determinate, if rigorously applied each theory would yield anomalous results that most legal interpreters could not stomach. The anomalies arise in part because none of the three anchors (intent, purpose, text) can altogether exclude the other two. Nor does any of them adequately accommodate evolutive factors-current values and policies, as well as the dynamics of the statutory policies as implemented over time. We illustrate these criticisms by reference to three Supreme Court cases which we believe were correctly decided but which, taken together, cannot be squared with any of the grand theories.

\section{A. Intentionalism}

The most popular grand theory is probably intentionalism. Under this view, the Court acts as the enacting legislature's faithful servant, discovering and applying the legislature's original intent. Traditional treatises on statutory interpretation generally acknowledge the primacy of legislative intent, qualifying the canons of construction with the caveat, "unless the legislature otherwise intends." "1 Although traditional intentionalism was subjected to withering attack in the 1930s and $1940 s,{ }^{12}$ recent scholarship has revived academic interest in the theory and posited some form of intentionalism as the anchor for a grand the-

11. This is perhaps most characteristic of 2A Sutherland Statutory Construction, supra note 9 , a leading treatise on statutory interpretation.

12. Max Radin was the most prominent critic. See Max Radin, Statutory Interpretation, 43 Harv. L. Rev. 863 (1930). For a later analysis, see Mfax Radin, A Short I'ay with Statutes, 56 HaRv. L. Rev. 388 (1942). For responses to Radin, see, e.g., R. Dickerson, supra note 9, at 6886 ; J. Hunst, supra note 9 , at $32-40$. 
ory of interpretation. ${ }^{13}$

Intentionalism makes a strong claim to be the only legitimate foundation for statutory interpretation in a representative democracy. If the legislature is the primary lawmaker and courts are its agents, then requiring the courts to follow the legislature's intentions disciplines judges by inhibiting judicial lawmaking, and in so doing seems to further democracy by affirming the will of elected representatives. Not surprisingly, then, a number of Supreme Court opinions state that original legislative intent is the touchstone for statutory interpretation. ${ }^{14}$

We shall explore three different versions of intentionalism, starting with the most obvious meaning - the actual intent of the legislators who enacted the statute. If a majority of our elected representatives had a certain interpretation in mind when they enacted a statute, that interpretation has obvious appeal in a representative democracy. But if the legislators did not clearly write that understanding into the statutory text, how can we figure out what they "intended"? It is hard enough to work out a theory for ascertaining the "intent" of individuals in tort and criminal law. To talk about the "intent" of the legislature, as that term is normally used, multiplies these difficulties, because we must ascribe an intention not only to individuals, but to a sizeable group of individuals-indeed, to two different groups of people (the House and the Senate) whose views we only know from the historical record. ${ }^{15}$ The historical record almost never reveals why each legislator voted for (or against) a proposed law, and political science scholarship teaches that legislators vote for bills out of many unknowable motives, including logrolling, loyalty or deference to party and committee, desire not to alienate blocks of voters, and pure matters of conscience. ${ }^{16}$ Most of these motives have little to do with the precise meaning, or the legislator's understanding, of the resulting legislative provisions.

Given these definitional and vote-counting problems, intentionalists usually speak of conventional, rather than actual, legislative intent.

13. See Richard A. Posner, The Federal Courts: Crisis and Reform 286-93 (1985); Earl M. Maltz, Statutory Interpretation and Legislative Power: The Case for a Modified Intentionalist Approach, 63 Tul. L. Rev. 1 (1988); Thomas W. Merrill, The Common Law Powers of Federal Courts, 52 U. CHI. L. Rev. 1, 33-39 (1985); Richard A. Posner, Statutony Interpretation-in the Classroom and in the Courtroom, 50 U. CHr. L. Rev. 800, 817 (1983).

14. See, e.g., Public Citizen v. United States Dep't of Justice, 109 S. Ct. 2558, 2566 (1989) (clear and unambiguous statutory language can be trumped by "other evidence of Congressional intent"); Blanchard v. Bergeron, 109 S. Ct. 939 (1989) (lower court counsel fee cases binding on Supreme Court because mentioned in a committee report and apparently approved by Congress); Commissioner v. Engle, 464 U.S. 206, 214 (1984) ("sole task" of Court in statutory interpretation is to determine congressional intent).

15. For this and other questions about aggregating collective intent, see Michael S. Moore, $A$ Natural Law Theory of Interpretation, 58 S. CAL. L. REv. 277 (1985); Radin, Stalulon Interpretation, supra note 12. See also Ronald Dworkin, How to Read the Civil Rights Act, in A Matter of Principle 316 (1985).

16. See, e.g., Roger H. Davidson \& Walter J. Oleszek, Congress and Its Members 388, 401 (2d ed. 1985); Melissa P. Collie, V'oting Behavior in Legislatures, in HaNdBook of LegisLATIVE Research 471-518 (G. Loewenberg, S. Patterson \& M. Jewell eds. 1985). 
Statements made in committee reports and floor statements by sponsors or floor managers of legislation presumably represent the legislature's views on specific issues. Conventional legislative intent is a second-best approach, for it can be fully legitimated by majoritarian norms only if legislators in general agree with, or at least acquiesce in, the views of the few actively involved in the passage of the legislation.

This notion of conventional intent, however, may be inconsistent with the actual operation of the legislative process. Committee members and bill sponsors are not necessarily representative of the entire Congress, ${ }^{17}$ and so it is not necessarily accurate to attribute their statements to the whole body. Moreover, any theory of interpretation that formally gives conclusive weight to the views of a legislative subgroup is in tension with the bicameralism and presentment requirements of article I. ${ }^{18}$ Article I, section 7 provides that legislation is not valid law unless it has been passed by both chambers of Congress and presented to (and in most cases signed by) the President; any enactment by just one chamber, or even two chambers without presentment, is not a statute. These procedural requirements, which exist to protect against factional lawmaking, were stringently enforced by the Court in the legislative veto case, INS v. Chadha. ${ }^{19}$ As a formal matter, therefore, a method of statutory interpretation that finds the meaning of a statute in the views of a committee and sponsors might seem close to the fragmented lawmaking that Chadha denounced. And as a functional matter, such a theory seems to present opportunities for factionalism and strategic manipulation that led the Court and some commentators ${ }^{20}$ to question the legislative veto: Interest groups often have their legislative allies pack committee reports and stage planned colloquies to suggest a meaning for the statute that they cannot place in the statutory language. ${ }^{21}$

In short, both actual and conventional approaches to legislative intent rest upon flawed assumptions about the legislative process. Not

17. The membership of a committee may not represent a cross-section of the legislature. Committee assignments are influenced by the legislators' desires for reelection and legislative influence. See Richard F. Fenno, Jr., Congressmen in Committees 1-21, 43-45, 69 (1973); Kenneth A. Shepsle, The Glant Jigsaw Puzzle (1978); see also Heinz Eulau, Committee Seleclion, in HANDBOoK of LEgislative RESEARCh, supra note 16, at 191-237. It is therefore unsurprising, for example, that the members of the House Agriculture Committee generally represent farm districts. See Michael. Barone \& Grant Ujifusa, The Almanac of American Politrcs 1336 (1988). Thus, even if a committee report could be presumed to represent the views of the median member of the committee majority, those views may not correlate well with the preferences of the median member of the legislature as a whole.

18. U.S. Const. art. I, § 7.

19. 462 U.S. 919 (1983). The Court noted that the President's veto power and the bicameralism requirement protect against the "fear that special interests could be favored at the expense of public needs." Id. at 950-51.

20. For an overview, see, e.g., Stanley C. Brubaker, Slouching Toutard Constitutional Duty: The Legislative l'eto and the Delegation of Authority, 1 Const. CommenTaRY 81, 90-101 (1984).

21. See, e.g., Robert A. Katzmann, Summary of Proceedings, in Judges AND Legislators: Toward Instrtutional Comity 162, 174-75 (R. Katzmann ed. 1988). 
surprisingly, these versions of intentionalism are also indeterminate in practice, as illustrated in the landmark case of United Steelworkers $v$. Weber. ${ }^{22}$ Weber arose under section 703(a)(1) of the Civil Rights Act of 1964, which makes it an unlawful employment practice "to discriminate against any individual" because of his or her "race, color, religion, sex, or national origin." 23 The broad issue in Weber was whether this language (or similar language in section 703(d), which applies to apprenticeship programs) bars the establishment of voluntary affirmative action plans for black workers. The report of the House Judiciary Committee on the civil rights bill in 1963 simply restated, in summary form, the terms of what was to become Title VII of the Act. The minority report, joined by Southern Democrats and a few conservative Republicans, noted that nowhere did the bill define the critical term "discriminate" and that "the administration intends to rely upon its own construction of 'discrimination' as including the lack of racial balance." 24 The minority report set forth several hypothetical situations, and concluded that if the civil rights bill were enacted an employer "may be forced to hire according to race, to 'racially balance' those who work for him in every job classification or be in violation of Federal law."25 The issue was not a major focus of the House floor debate, but the Chair of the Judiciary Committee claimed that the minority report overstated the effect of the bill. ${ }^{26}$ Other supporters echoed the view that " $[t]$ here is nothing here as a matter of legislative history that would require racial balancing." 27 After this debate, and with only one material amendment to the jobs title (adding a prohibition against discrimination based upon gender), the House approved the bill by a vote of 290 to 130.

What was the "intent" of the House of Representatives on the Weber issue? However defined, the House's intent is indeterminate. The Southerners suggested that the bill went even beyond the result that was later reached in Weber, but obviously they were trying to scare away potential supporters of the bill. By denying that the bill required "racial balancing" (whatever that means), supporters of the bill behaved just as strategically, trying to soothe concerns that the bill was too radi-

22. 443 U.S. 193 (1979).

23. 42 U.S.C. $\$ 2000 \mathrm{e}-2(\mathrm{a})(1)$ (1982).

24. H.R. ReP. No. 914, 88th Cong., lst Sess., pt. 1, at 67-68, reprinted in 1964 U.S. Code Cong. \& Admin. News 2431, 2436.

25. Id. at 69, reprinted in 1964 U.S. CODE Cong. \& ADMin. NEws at 2438 (emphasis omitted). In a separate statement, the moderate Republican supporters of the bill said that its enforcement "must confine its activities to correcting abuse, not promoting equality with mathematical certainty." Id. at 29, reprinted in 1964 U.S. CODE CONG. \& ADMIN. News at 2516. "All vestiges of inequality based solely on race must be removed." Id. at 30, reprinted in 1964 U.S. Code Cong. \& Admin. News at 2517.

26. He denied that the EEOC would have a roving mandate to correct any existing racial imbalances. "Only actual discrimination could be stopped." 110 CoNG. REc. 1518 (1964) (remarks of Rep. Celler).

27. Id. at 2558 (remarks of Rep. Goodell). 
cal. Indeed, if the Weber issue had been brought to a vote as an amendment to the jobs title, it is hard to predict how the vote would have gone. Many Southerners might have voted in support for affirmative action, hoping to kill the bill by making it too strong. ${ }^{28}$ Some Republicans and Democrats would have joined them because of sincere support of affirmative action. Other supporters of the bill would have voted against affirmative action, to attract moderate support for the overall legislation. Perhaps many House members would have abstained.

Moreover, even if it could be discovered, the intent of the House is not the intent of Congress. Whatever inferences one draws about the intent of the House must somehow be matched to the intent of the Senate. A similar debate about affirmative preferences occurred in the Senate, with similar posturing by interested Senators. Unlike the House, however, the Senate amended the civil rights bill to add a provision touching upon the issue. Section 703(j), added as part of a compromise bill, provides that nothing in Title VII "shall be interpreted to require any employer ... to grant preferential treatment . . to to any group because of the race ... of such ... group on account of" a de facto racial imbalance in the employer's workforce. ${ }^{29}$ This provision was part of the bill that passed the Senate, was accepted by the House, and was signed by the President. Unhappily, section 703(j) addresses only "requir[ing]" employers to grant preferences, not whether employers are "permitted" to do so. As a formal matter, nothing more seems relevant. Congress addressed the issue in section 703(j); any ambiguities simply reflect lack of legislative intent, to be resolved by the courts. In this case, substance follows form, since the legislative record affords us no better explanation of what the Members, or the committees, or the sponsors wanted the bill to do. The intent of Congress provides no clear answer to the interpretive puzzle in Weber. ${ }^{30}$

In addition to the actual and conventional approaches to intentionalism is the version articulated by Judge Posner, "imaginative reconstruction." ${ }^{1}$ Under this theory, the judge should imagine that she is talking to the legislators at the time of enactment and should reconstruct how the legislators would have answered the interpretive question, given their values and their concerns. Where Congress has

28. Indeed, Title VII's prohibition on gender discrimination in employment was adopted at least in part for similar reasons: House opponents of the Givil Rights Act strategically proposed and voted for the gender discrimination amendment in the hope that it would kill the whole bill. See Charles Whalen \& Barbara Whalen, The Longest Debate: A LegisLAtive History OF THE 1964 Civil Rights ACt 115-17 (1985).

29. 42 U.S.C. $§ 2000 \mathrm{e}-2$ (j) (1982) (emphasis added).

30. For an interesting and somewhat similar discussion of the indeterminacy of Congressional intent surrounding the Voting Rights Act amendments of 1982, see J. Morgan Kousser, Expert Witnesses, Rational Choice and the Search for Intenl, 5 Const. Commentary 349, 361-63 (1988).

31. See R. Posner, Federal Courts, supra note 13, at 286. 
written a statute broadly or where its concerns do not allow us to reconstruct its imagined intent, courts should simply seek the most reasonable interpretation. While we believe Judge Posner's theory of imaginative reconstruction is more sensible than other versions of intentionalism, it too is subject to three critical problems.

First, the theory rests upon the questionable assumption that judges will be able to recreate the historical understanding of a previous legislature. Modern historiography suggests that a present-day interpreter can never completely or accurately reconstruct past understandings. ${ }^{32}$ Facts about the past are without meaning until they are woven together into a narrative by the historian (or judge). The nature of the story will vary according to the way the storyteller selects and interprets the facts. And in choosing and interpreting facts, even the most scrupulous historian will be influenced by her own biases, meta-theories, and desired conclusions. This effect will be most palpable in hard cases. There, judicial interpretation will most clearly be affected by the current context of the judicial interpreter. And the greater the distance between the current and historical contexts of the statute the more implausible will be the claims of intentionalist interpretation.

In Weber, for example, the majority and dissenting Justices saw themselves as amateur historians, imaginatively reconstructing the answer to the interpretive puzzle. The majority and the dissenting opinions looked at the same evidence and yet told vastly different stories of what the Civil Rights Act meant, both generally and specifically in connection with affirmative action. ${ }^{33}$ We do not believe that either group of Justices was being dishonest. Rather, each was interpreting evidence from very different perspectives on racial justice and political philosophy. Neither group was-or, we argue, could be-entirely capable of replicating the original response that Congress would have made to the interpretive inquiry. Note, here, that the Court was examining a recently enacted statute, passed only fifteen years before the Court's opinion. Consider how much more complex the task would have been for an older statute.

Second, Judge Posner's theory is indeterminate, because it often . asks counterfactual questions of a long-departed legislature. In the hard cases, the interpretive issue will not have been precisely anticipated by the legislature. Every statute carries with it certain assumptions about the nature of law and society. Often, those assumptions turn out to be wrong, or simplistic, or obsolescent in light of social change-change that sometimes occurs in response to the statute itself.

32. For detailed examinations of this problem by two leading legal historians, see William E. Nelson, History and Neutrality in Constitutional Adjudication, 72 VA. L. REv. 1237 (1986); G. Edward White, The Text, Interpretation, and Critical Siandards, 60 TEx. L. Rev. 569 (1982).

33. Compare I'eber, 443 U.S. at 201-09 (majority opinion by Brennan, J.) (Civil Rights Act adopted to open doors for historically disadvantaged minorities), with id. at 219-55 (Rehnquist, J., dissenting) (statute adopted to promote a color-blind society). 
As the assumptions prove incorrect, the statute inevitably deviates from its original course, by an often imperceptible process of implementation and interpretation. But once such changes have occurred, how should an intentionalist judge even ask the interpretive question? Should she try to ask how the enacting legislature, independent of context, would have answered the question? Or how that legislature would have answered the question if it had realized how society would change?

For example, the Weber dissent made a good case for the proposition that if the Senators and Representatives in 1964 had been asked the question, "Do you want to allow voluntary quotas in hiring?" they would have answered (if they were not voting strategically), "No, we want to eliminate racial categories from employment decisions." 34 The majority opinion seemed to ask a different question of the original legislators: "Would you allow voluntary preferences if it could be shown that after 15 years an employer had less than 2 percent blacks in its craft force, even though over 39 percent of the area's workforce is black, and that the disparity is probably the result of the continuing effects of past discrimination?" 35 One can quite plausibly say that the legislators in 1964 would have answered "Yes" to this form of the question. Which of these questions is truer to the intentionalist approach? Which is the more accurate reconstruction? We see no clear answers to these queries.

Third, Judge Posner's focus on reconstructing original legislative intent slights other values that we should respect when interpreting statutes. At least some statutory schemes ought to be efficacious over time and across changing circumstances. ${ }^{36}$ As the statute changes in unexpected ways, the original legislative expectations may prevent the statute from adapting to present conditions. To return to our prior

34. See generally id. at 230-55 (Rehnquist, J., dissenting).

35. See id. at 203-04 \& n.4 (majority opinion). See also id. at 209-16 (Blackmun, J., concurring), for a more forthright consideration of events occurring after the passage of the statute.

36. A recent British treatise makes the point well. See F. BENNIon, supra note 9, §§ 146,

$163,235,326$. For our purposes, it is worth quoting a small portion of Bennion's views:

Each generation lives under the law it inherits. Constant formal updating is not prac-

ticable, so an Act takes on a life of its own. What the original framers intended sinks gradually into history. While their language may endure as law, its current subjects are likely to find that law more and more ill-fitting.

The intention of the originators, collected from an Act's legislative history, necessarily becomes less relevant as time rolls by. Yet their words remain law. Viewed like this, the ongoing Act resembles a vessel launched on some one-way voyage from the old world to the new. The vessel is not going to return; nor are its passengers. Having only what they set out with, they cope as best they can. On arrival in the present, they deploy their native endowments under conditions originally unguessed at.

Id. at 356. Bennion asserts that a British statute is a "living Act" somewhat similar to the American "living Constitution," id. at 356-57, and thus that "the intentions of the historical legislator may not indefinitely continue to carry interpretative weight (or at least the same weight)." Id. at 521 . 
example, the implementation of Title VII by the EEOC and private parties generated unanticipated tensions within the statutory scheme, such as whether to permit facially neutral job classifications that in effect disproportionately disadvantaged certain racial groups. After the EEOC and the courts had gained much experience with this issue, the Supreme Court in 1971 held that a violation of Title VII could be established by showing that the practice had racially disparate effects without substantial job-related justifications. ${ }^{37}$ This decision had two important effects on the way Title VII was understood. First, it underscored the idea that results matter-as the Court put it, "practices, procedures, or tests neutral on their face, and even neutral in terms of intent, cannot be maintained if they operate to 'freeze' the status quo of prior discriminatory employment practices." 38 Second, it created a practical problem for employers and unions. Even if they did not intend to treat blacks differently from whites, they faced potential Title VII liability if substantial racial imbalance in their workplace persisted over time. What could such employers and unions do but adopt some form of voluntary preference programs to improve the statistics?

In 1964, Congress expected-or at least pretended to expect-that if racial discrimination were eliminated in employment, blacks would gain employment opportunities long denied them. That did not always happen. The original intent of Congress on this issue is thus not very helpful in solving a critical problem of implementing the statute. The Weber result addresses this problem by permitting voluntary preferences, at least where racial imbalance has persisted and the overall purposes of the statute are not being served. This justification of Weber, made in a concurring opinion, ${ }^{39}$ is on the whole the most narrow, and most persuasive, justification for the result. It looks past original intent to the practical operation of the statutory scheme.

\section{B. Purposivism}

The legal realists—especially Max Radin-raised some of the objections to intentionalism noted above and proposed as an alternative theory a flexible "mischief" approach to statutory interpretation.40 Professors Henry Hart and Albert Sacks in the 1950s expanded the realists' approach into a "purposivist" theory of interpretation that seemed as faithful to the principle of legislative supremacy as intention-

37. Griggs v. Duke Power Co., 401 U.S. 424 (1971), qualified in Wards Cove Packing Co. v. Atonio, 109 S. Ct. 2115 (1989).

38. Griggs, 401 U.S. at 430 .

39. I'eber, 443 U.S. at 209-16 (Blackmun, J., concurring) (following 563 F.2d 216, 22739 (5th Cir. 1977) (Wisdom, J., dissenting)).

40. In a nutshell, the Court should determine what mischief, or ill, the legislature had targeted in passing the statute and then should interpret the statute to attack that mischief as manifested under current circumstances. See Jerome Frank, Words and Music: Some Remarks on Statutory Interpretation, 47 CoLum. L. REv. 1259, $1269-72$ (1947); Radin, A Short W'ay' with Statutes, supra note 12 , at 398-99. 
alism, but without the rigidity and definitional problems of intentionalism. According to the Hart and Sacks legal process materials, ${ }^{41}$ "[e]very statute must be conclusively presumed to be a purposive act. The idea of a statute without an intelligible purpose is foreign to the idea of law and inadmissible." 42 Because "every statute and every doctrine of unwritten law developed by the decisional process has some kind of purpose or objective," identifying that purpose and deducing the interpretation with which it is most consistent resolves interpretive ambiguities. ${ }^{43}$

As an alternative to intentionalism, purposivism has been rather successful, and some commentators believe that it is now the "traditional" theory of statutory interpretation. ${ }^{44}$ The Supreme Court appears to rely on this approach frequently, as it did in Weber, to reject interpretations that, while plausibly grounded in statutory text and history, would " 'bring about an end completely at variance with the purpose of the statute." "45 On the other hand, purposivism is subject to the same problems as intentionalism-unrealistic assumptions, indeterminacy, and competing values. We shall explore those problems in connection with Weber and conclude with an examination of the Supreme Court's decision in Griffin v. Oceanic Contractors, Inc. ${ }^{46}$ a decision rejecting purposivist theory as the foundation for statutory interpretation.

First, purposivism's apparent majoritarian justifications rest upon

41. Henry M. Hart, Jr. \& Albert M. Sacks, The Legal Process: Basic Problems in the Making and Application of Law (tentative ed. 1958). For an overview of the Hart \& Sacks materials, see William N. Eskridge, Jr. \& Philip P. Frickey, Legislation Scholarship and Pedagogy in the Post-Legal Process Era, 48 U. PITT. L. Rev. 691, 693-700 (1987).

42. 2 H. HART \& A. SACks, supra note 41, at 1156. Hart and Sacks do not take a hardand-fast position on this and other issues posed in the text, for they ask, "Are the following conclusions well founded?" Id. We consider this a rhetorical question.

43. I Id. at 166-67; se 2 id. at $1148-79$ (more extensive analysis of the purposivist approach to statutory interpretation). Hart and Sacks formally announced their approach to statutory interpretation in the following "tentative formulation":

In interpreting a statute a court should:

1. Decide what purpose ought to be attributed to the statute and to any subordinate provision of it which may be involved; and then

2. Interpret the words of the statute immediately in question so as to carry out the purpose as best it can, making sure, however, that it does not give the words either-

(a) a meaning they will not bear, or

(b) a meaning which would violate any established policy of clear statement.

Id. at 1200

44. See, e.g., Jonathan R. Macey, Promoting Public-Regarding Legislation Through Statutory Interpretation: An Interest Group . Model, 86 Colum. L. Rev. 223, 250-51 (1986).

45. I'éber, 443 U.S. at 202 (quoting United States v. Public Util. Comm'n, 345 U.S. 295, 315 (1953)). For recent examples in which the Court relies on overall statutory purpose as the key argument, see EEOC v. Commercial Office Prods. Co., 108 S. Ct. 1666, 1671-74 (1988); United States v. Fausto, 484 U.S. 439, 443-48 (1988); School Bd. of Nassau County v. Arline, 480 U.S. 273, $277-80$ (1987); California Fed. Sav. \& Loan Ass'n v. Guerra, 479 U.S. $272,284-86$ (1987).

46. 458 U.S. 564 (1982). 
questionable assumptions about the legislative process. Hart and Sacks assumed that the legislature is filled with reasonable people who will reach reasonable, purposive results by following established procedures. ${ }^{47}$ Whether Hart and Sacks thought this assumption reflected the realities of the legislative process is unclear. But it was a plausible working assumption for the legal community in the 1950s, given the state of political science. ${ }^{48}$ And since Hart and Sacks expressed no caveat along these lines, much less attempted any elaborate normative justification for these assumptions if they were deemed unrealistic, it appears that at least some of the legitimacy of their approach depends upon the empirical accuracy of these assumptions.

These optimistic legal process assumptions have received a considerable amount of theoretical and empirical testing since the 1950s and must now be considered naive. Public choice theory, the application of economic analysis to public decisionmaking, ${ }^{49}$ posits that "rational" legislators responding to rational interest groups will not, in fact, produce purposive statutes. Economic game theory suggests that, frequently, nothing more than who controls the legislature's agenda determines legislative results. ${ }^{50}$ Interest group theory suggests that much legislation simply distributes benefits to well-organized groups, typically at the expense of the general public. ${ }^{51}$ To speak of a statute's "purpose" is incoherent, unless one means the deal between rent-seeking groups and reelection-minded legislators. To be sure, public choice is a controversial approach to legislation, ${ }^{52}$ but the insights

47. See 2 H. HART \& A. SACKs, supra note 41 , at 1415 (court "should assume, unless the contrary unmistakably appears, that the legislature was made up of reasonable persons pursuing reasonable purposes reasonably"). The statutes adopted by these legislators are conclusively presumed to be purposive acts. See text accompanying note 42 supra. Legislation is viewed as the result of an informed, deliberative, and efficient process. See Eskridge \& Frickey, supra note 41 , at 696-97.

48. Leading authorities in the 1950 s posited that politics involved the interplay of interest groups and that this usually resulted in good policy because groups formed on all sides of important issues. See, e.g., Wilfred E. Binkley \& Malcolm C. Moos, A Gramimar of American Politics (1949); Earl latham, The Group Basis of Politics (1952); David B. Truman, The Governmental Process (1951); see also Theodore J. Lowi, The End of Liberalism 51 (1969).

49. This approach is summarized and its implications explored in William N. Eskridge, Jr., Politics I'ithout Romance: Implications of Public Choice Theory for Statutory Interpretation, 74 VA. L. Rev. 275 (1988); Daniel A. Farber \& Philip P. Frickey, The Jurisprndence of Public Choice, 65 TEx. L. Rev. 873 (1987). Leading works include James M. Buchanan \& Gordon Tullock, The Calculus of Consent: logical foundations of Constitutional Democracy (1962); Mancur Olson, The logic of Collective Action: Public Goods and the Theory of Groups (1965); George J. Stigler, The Theory of Economic Regulation, 2 BELL J. ECON. \& MGMT. Scr. 3 (1971).

50. See J. Buchanan \& G. Tullock, supra note 49 .

51. In addition to the sources in note 49 supra, see Morris P. Fiorina, Congress: KeyStone of the Washington Establishment (1977); Michael T. Hayes, Lobbyists and Legislators: A Theory of Political Markets (1981); David R. Mayhew, Congress: The Electoral Connection (1974); James Q. Wilson, Political Organizations (1973).

52. See generally Mark Kelman, On Democracy-Bashing: $A$ Skeplical Look at the Theoretical and "Empirical" Practice of the Public Choice Movemenl, 74 VA. L. Rev. 199 (1988). 
presented here-the potential arbitrariness and unfairness of many legislative decisions-are supported by more traditional institutional political theory as well. Leading scholars of legislative institutions stress the ability of committees and power figures to manipulate legislative procedure, ${ }^{53}$ and the importance of "subgovernments" of bureaucrats, lobbyists, and subcommittee leaders who push the legislative agenda toward distributing favors to organized groups. ${ }^{54}$

Modern political theory, especially public choice theory, renders the political theory assumptions of purposivist statutory interpretation highly controversial. It seems clear not only that reasonable people in the legislature do not always produce reasonable results, but that in some cases that is the last thing they want to do. Some statutes are little else but backroom deals. Judicial attempts to fancy up those deals with public-regarding rhetoric either are naive or simply substitute the judge's conception of public policy for that of the legislature. And when a court uses purposivist analysis to elaborate a statute, it may actually undo a deliberate and precisely calibrated deal worked out in the legislative process. ${ }^{55}$ Such judicial lawmaking can often be justified, we think, but the point is that this is judicial lawmaking and not, as some legal process thinkers might suggest, merely carrying out the original statutory purposes.

Second, purposivism is indeterminate, for some of the reasons just developed. The complex compromises endemic in the political process suggest that legislation is frequently a congeries of different and sometimes conflicting purposes. To be enacted, a statute must be acceptable to a range of interest groups, each of which will have their own reasons for supporting, or at least not opposing, the statute. Some commentators argue that these various purposes cannot be aggregated into a public purpose. ${ }^{56}$ Moreover, even if such an aggregation were theoretically possible, supporters of legislation will usually appeal to more than one public purpose in order to maximize political support.

53. See, e.g., Terry Sullivan, Procedural Structure: Success and Influence in ConGRESS (1984).

54. See, e.g, Randall B. Ripley \& Grace A. Franklin, Congress, the Bureaucracy, AND Public Policy 6-10, 13-28 (4th ed. 1987). Even one of the leading theorists who believes that Congress is often public-seeking nonetheless describes it as an "organized anarchy." John W. Kingdon, Agendas, Alternatives, and Public Policies 48-74 (1984).

55. As the Court itself has recognized:

Application of "broad purposes" of legislation at the expense of specific provisions ignores the complexity of the problems Congress is called upon to address and the dynamics of legislative action. Congress may be unanimous in its intent to stamp out some vague social or economic evil; however, because its Members may differ sharply on the means for effectuating that intent, the final language of the legislation may reflect hard-fought compromises. Invocation of the "plain purpose" of legislation at the expense of the terms of the statute itself takes no account of the processes of compromise and, in the end, prevents the effectuation of congressional intent.

Board of Governors of Fed. Reserve Sys. v. Dimension Fin. Corp., 474 U.S. 361, 373-74 (1986).

56. For an overview, see Macey, supra note 44 , at 227-33. 
Reconsider Title VII and the Weber case in light of these two criticisms of purposivism. Title VII seems to be one of the most purposive statutes we have adopted in the last 30 years, and its requirement of nondiscrimination is a great purpose. Yet that purpose is compromised in many ways by statutory exceptions for small businesses, union seniority arrangements, and so forth. ${ }^{57}$ Thus, it is not a principle that Congress was willing to implement at any price. How, then, can the overall purpose control statutory interpretation, when it is clear that Congress itself did not believe in it without reservation? Moreover, the general nondiscrimination purpose of Title VII does not help us answer the interpretive question in Weber, where the issue is the very meaning of "discrimination." The Court's reasoning seized upon one specific purpose of Title VII to create the following syllogism: (1) Congress's purpose was to move blacks into mainstream jobs; (2) affirmative action is a useful way to speed up the process of getting more jobs for blacks; therefore, (3) affirmative action is permissible under the statute because it is consistent with the statute's purpose. ${ }^{58}$ This line of reasoning is made compelling only by romanticizing the legislative process and subordinating other purposes of Title VII.

Weber's evidence that the purpose of Title VII was to obtain jobs for blacks was a series of quotations from the Senate debates and from President Kennedy's speech proposing the legislation. All of the quotations came from liberal Democrats-Senators Humphrey, Clark, and Edward Kennedy, as well as the President. So what? If the Court is trying to show that the entire Senate, let alone the entire Congress, believed that the main purpose of the employment discrimination title was to obtain real results, the evidence is pretty flimsy. Although Humphrey and Clark were key players in the debate, their views were not necessarily representative of the twenty-seven Republicans who supported the bill, or even of the approximately twenty western and border state Democrats who supported the bill. More representative of the views of supporting Republican conservatives were the statements of Senator Dirksen, the Senate Minority Leader, who found the bill's central purpose to be "equality of opportunity," not equality of results. ${ }^{59}$ For Dirksen, therefore, the purpose of the bill was to assure color-blind decisions in employment. That purpose is not carried out by affirmative action, which is color-conscious. By asserting the "results purpose" and ignoring the "color-blindness purpose," Weber subordinates one plausible purpose of Title VII to another, without any effort to acknowledge the subordination, much less justify it. In an effort to support its decision in terms of original legislative expectations,

57. See 42 U.S.C. $\$ 2000$ e(b) (1982) (definition of "employer" excluding federal government, private clubs, and businesses with fewer than fifteen employees); id. $\$ 2000 \mathrm{e}-2$ (h) (protecting bona fide seniority systems).

58. Weber, 443 U.S. at 202-04.

59. See 110 CONG. REG. 14,510 (1964) (remarks of Sen. Dirksen). 
then, Weber overstates its argument and distorts the evidence. At best, the Weber result is judicial gapfilling of an indeterminate statute. At worst, it is judicial lawmaking inconsistent with legislative supremacy. ${ }^{60}$

Third, although purposivism often permits statutes to develop over time, as Weber may illustrate, purposivism cannot be accepted as a general theory because it neglects other values we consider critically important. Representative democracy places some value on faithfulness to original legislative intentions. It also is committed to following determinate texts: Because text is the only thing actually enacted into law, it is formally the most legitimate expression of legislative intent or purpose. Moreover, it is argued, citizens ought to be able to rely on clear statutory text to determine their rights and duties.

For this last reason in particular, the Supreme Court often finds the intentionalist and the purposivist approaches insufficient and purports to rely simply on the statutory text. Several recent opinions take this position, ${ }^{61}$ including the celebrated snail darter case, ${ }^{62}$ but we shall use a less well-known decision, Griffin v. Oceanic Contractors, Inc. ${ }^{63}$ Griffin, a welder working on Oceanic's vessels in the North Sea, was injured during his employment and subsequently discharged. Oceanic withheld $\$ 412.50$ in earned wages. Griffin brought suit under a federal statute that required certain maritime employers to pay wages within a specified period after terminating a seaman's employment. The statute further provided: "Every master or owner who refuses or neglects to make payment in the manner hereinbefore mentioned without sufficient cause shall pay to the seaman a sum equal to two days' pay for each and every day during which payment is delayed beyond the re-

60. Compare Daniel A. Farber, Statutory Interpretation and Legislative Supremacy, 78 GEO. L.J. 281 (1989) (arguing that the majority opinion in Weber is inconsistent with legislative supremacy) with William N. Eskridge, Jr., Spinning Legislative Supremacy, 78 GEo. L.J. 319 (1989) (arguing that Weber is consistent with legislative supremacy).

61. See United States v. Ron Pair Enters., 109 S. Ct. 1026, 1030-32 (1989) (plain meaning of statute, established by "punctuation rule," trumps established judicial interpretations prior to statutory revision); Pittston Coal Group v. Sebben, 109 S. Ct. 414, $419-23$ (1988) (plain meaning controls, notwithstanding argument that text contained "scrivener's error"); Board of Governors of Fed. Reserve Sys. v. Dimension Fin. Corp., 474 U.S. 361,373 (1986) ("The 'plain purpose' of legislation ... is determined in the first instance with reference to the plain language of the statute itself."); United States v. Locke, 471 U.S. 84 (1985); North Dakota v. United States, 460 U.S. 300, 312-14 (1983) (language conclusive absent clear contrary purpose); Howe v. Smith, 452 U.S. 473, 483 (1981) (not one of those "rare and exceptional" cases where the Court will go beyond unambiguous language); Consumer Prod. Safety Comm'n v. GTE Sylvania, Inc., 447 U.S. 102, 108 (1980) (no clear legislative intent contrary to the statutory language); Reiter v. Sonotone Corp., 442 U.S. 330, 337-39 (1979); United Air Lines, Inc. v. McMann, 434 U.S. 192, 199 (1977) (legislative history irrelevant if statute unambiguous) (superseded by statute as stated in Western Air Lines v. Criswell, 472 U.S. 400 (1985)). See generally Intent, Clear Statements, and the Common Law: Statutory Interpretation in the Supreme Court, 95 HaRv. L. REv. 892 (1982) (student author).

62. Tennessee Valley Auth. v. Hill, 437 U.S. 153, 173-74 (1978) (plain language of federal statute forbade completion of $\$ 107$ million dam project that would result in destruction of a species of fish known as the snail darter) (superseded by statute as stated in Board of Governors of Fed. Reserve Sys. v. Dimension Fin. Corp., 474 U.S. 361 (1986)).

63. 458 U.S. 564 (1982). 
spective periods ...."64 The trial court found Oceanic liable for the withheld wages and assessed the penalty for the period between discharge (1 April 1976) and Griffin's reemployment (5 May 1976); the penalty amounted to $\$ 6,881.60$. The Supreme Court directed that the penalty be recalculated to reflect the period between discharge and the actual date of payment of the $\$ 412.50$ (which was not until after the trial court's judgment). The Court relied on the literal terms of the statute, which says that the owner "shall pay" penalty wages "for each and every day during which payment is withheld"; no exceptions appear on the face of the statute. Hence, the penalty became $\$ 302,790.40$, by the Court's calculations.

This striking result was disputed in a dissenting opinion by Justice Stevens, who relied on both legislative intent and purpose to argue that the penalty statute gave trial courts discretion to toll the penalty period at an equitable time. The original statute, enacted in 1872, used mandatory language ("shall") to assure that additional wages were awarded, but double wages could only be awarded for up to ten days, and courts had discretion to award even less than that. ${ }^{65}$ Congress amended the statute in 1898 to eliminate the ten-day limit, but it retained the mandatory language. ${ }^{66}$ Given the fairly routine nature of the 1898 amendment and the absence of legislative comment, the dissent suggested that Congress did not intend to abrogate judicial discretion to award less than the maximum amount. More important, the Court's broad interpretation of the 1898 change would go well beyond the statute's purpose, which was simply to compensate seamen for additional expenses incurred after discharge (often in a foreign land), not afford them a windfall. ${ }^{67}$

Like many intentionalist and purposivist arguments, these are not as determinate as they seem. The critical 1898 amendment actually did two important things: it eliminated the ten-day cap on recovery, and it

64. 46 U.S.C. $\$ 596$ (repealed 1983).

65. Act of June 7,1872 , ch. $322, \S 35,17$ Stat. 269 :

[E]very master or owner who neglects or refuses to make payment [of a seaman's earned wages within five days after a seaman's discharge] without sufficient cause shall pay to the seaman a sum not exceeding the amount of two days' pay for each of the days, not exceeding ten days, during which payment is delayed beyond [the fiveday period] and such sum shall be recoverable as wages in any claim made before the court....

66. Act of Dec. 21,1898 , ch. $28, \S 4,30$ Stat. 756 :

Every master or owner who refuses or neglects to make payment [of a seaman's earned wages within four days of the seaman's discharge] without sufficient cause shall pay to the seaman a sum equal to one day's pay for each and every day during which payment is delayed beyond the [four-day period], which sum shall be recoverable as wages in any claim made before the court....

As appears from the text, the 1898 statute also changed the period of permissible delay (from five to four days) and made the penalty single rather than double wages. The latter change was reversed by the Act of Mar. 4, 1915, ch. 153, § 3, 38 Stat. 1164, which substituted "two days" pay" for "one day's pay."

67. Griffin, 458 U.S. at 588-89 \& n.19 (Stevens, J., dissenting). 
rewrote the statute as a whole to delete the explicit grant of judicial discretion. The committee reports identified the purpose of the 1898 amendment as "the amelioration of the condition of the American seamen" and stated that the strengthened penalty wage provision was "designed to secure the promptest possible payment of wages." $68 \mathrm{Un}$ happily, none of the legislative materials tells us exactly how draconian Congress expected penalty wages to be. Nor is the general purpose of the statute instructive. If the statute's purpose was merely to compensate seamen for incidental expenses while they relocated and found new employment, and no stringent deterrence or punishment of the employer was intended, then the dissent's interpretation is correct. If, on the other hand, the statute was meant strongly to deter withholding of wages from vulnerable seamen, then the Court's interpretation is perhaps correct-but only if Congress suspected that judges (few of whom had represented seamen in private practice and more of whom had represented vessels) would otherwise fudge on the punitive sanction. ${ }^{69}$

Even if the statutory purpose had supported the dissent's position more clearly, a majority of the Justices would probably have reached the same result in Griffin, because of the competing value the Court found in enforcing the relatively clear statutory text. Citizens ought to be able to open up the statute books and have a good idea of their rights and obligations. When the statute seems plainly to say one thing, courts should be reluctant to alter that directive. Thus, in Griffin the Court sent a message to vessel owners: The provisions of the maritime code set forth some pretty clear obligations, which judges will enforce to the letter. This discourages owners, who obviously have greater resources than seamen, from engaging in strategic wage withholding or dilatory litigation. And it signals to the owners and the seamen that the law will be applied to them in a predictable manner..$^{70}$

68. H.R. REP. No. 1657, 55th Cong., 2d Sess. 2, 3 (1898); see Griffin, 458 U.S. at 572-74.

69. Justice Stevens' approach in Griffin is somewhat similar to an "absurd result" exception to statutory plain meaning. See generally 2 H. HART \& A. SACKS, supra note 41 , at 1144 (labeling this the "golden rule" of statutory interpretation). Even conceding the validity of this "rule" fails to provide a determinate answer in Griffin. If one asks whether it seems absurd that Griffin gets over $\$ 300,000$ when only $\$ 412$ was wrongfully withheld and he promptly obtained reemployment, the answer would seem to be affirmative. But if one concludes that the award in Griffin will deter maritime system-wide abuse of a relatively defenseless class of employees, that result seems quite plausible.

In the end, one of us is comfortable with the outcome in Griffin. The other is uncomfortable, but leaning in that direction as well. Both of us agree that the statute has more than merely a compensatory purpose; how much more is the key question. At all events, a "purpose approach" in Griffin seems mostly to beg the question, not resolve it.

70. Indeed, in 1983, as part of a major recodification, Congress repealed the penalty statute at issue in Griffin, but replaced it with one containing precisely the same kind of mandatory language. See Pub. L. No. 98-89, 97 Stat. 566 (1983) (codified at 46 U.S.C. $\$ 10313(\mathrm{~g})$ (Supp. $V$ 1987)). The legislative history reveals that Congress was engaged in merely a recodification and wished to avoid considering substantive changes that could cause substantial interest-group turmoil. See H.R. REP. No. 338, 98th Cong., 1st Sess. 117-20 (1983), reprinted in 1983 U.S. Code Cong. \& Admin. News 929-32. Yet the House committee 


\section{Textualism}

The legal realists and legal process thinkers discredited intentionalism as a grand strategy for statutory interpretation; in its place they suggested purposivism. That theory has in turn been extensively criticized, especially by scholars influenced by the law and economics movement. As argued above, the recent trend is to view the legislature as not necessarily purposive; "attributing" purposes to ad hoc statutory deals is nothing if not judicial lawmaking. Accordingly, several judges of the law and economics school have responded to the critique of purposivism by urging as a grand theory the return to some version of the old "plain meaning rule": The beginning, and usually the end, of statutory interpretation should be the apparent meaning of the statutory language. ${ }^{71}$

The arguments for textualism are strong ones. As suggested above, textualism appeals to the rule-of-law value that citizens ought to be able to read the statute books and know their rights and duties. By emphasizing the statutory words chosen by the legislature, rather than (what seem to be) more abstract and judicially malleable interpretive sources, textualism also appeals to the values of legislative supremacy and judicial restraint.

There are at least two varieties of textualism. The stricter version posits the statutory text as (at least ordinarily) the sole legitimate interpretive source. A characteristically pithy Holmesianism says it well: "We do not inquire what the legislature meant; we ask only what the statute means." 72 The second, and less ambitious, variety of textualism

report strongly endorsed textualism rather than intentionalism or purposivism as the appropriate interpretive method:

The Committee intends and hopes that the interpretation of the maritime safety laws as codified and enacted by this bill will be based on the language of the bill itself. The bill, as reported, is based on that premise. There should, therefore, be little or no occasion to refer to the statutes being repealed in order to interpret the provisions of this bill.

The Committee also feels, as the courts have held, that the literal language of the statute should control the disposition of the cases. There is no mandate in logic or in case law for reliance on legislative history to reach a result contrary to the plain meaning of the statute, particularly where that plain meaning is in no way unreasonable.

H.R. Rep. No. 338, supra, at 120, reprinted in 1983 U.S. Code Conc. \& Admin. News 932.

71. Namely, Justice Scalia, see K Mart Corp. v. Cartier, Inc., 108 S. Ct. 1811, 1831-34 (1988) (Scalia, J., concurring in part and dissenting in part) (plain meaning approach, and clearly not purpose approach, is required by democratic theory); INS v. Cardoza-Fonseca, 480 U.S. 421, 452 (1987) (Scalia, J., concurring in the judgment) ("if the language of a statute is clear, that language must be given effect at least in the absence of a patent absurdity"); Hirschey v. FERC, 777 F.2d 1, 7-8 (D.C. Cir. 1985) (Scalia, J., concurring); Address by Judge Antonin Scalia, Speech on Use of Legislative History (delivered in different forms at various law schools, 1985-86), discussed in Farber \& Frickey, Legislative Intenl, supra note 3, at 442-43; and Judge Easterbrook, see Frank H. Easterbrook, Statules' Domains, 50 U. CHI. L. Rev. 533, 544 (1983); $c f$. United States v. Medico Indus., Inc., 784 F.2d 840, 844 (7th Cir. 1986) (Easterbrook, J.) (when Congress changes the rule rather than the objective the rule is to serve, the courts must reject claims attacking the rule in the name of the objective).

72. Oliver Wendell Holmes, The Theory of Legal Interpretation, 12 HaRv. L. REv. 417, 419. 
uses statutory language not in place of, but rather as the best guide to, legislative intent or purpose. "There is, of course, no more persuasive evidence of the purpose of a statute than the words by which the legislature undertook to give expression to its wishes."73 Similarly, "when words are free from doubt they must be taken as the final expression of the legislative intent."74 As a grand theory, both versions of textualism suffer from similar defects: They oversimplify the meaning of statutory texts, are not so determinate as they sound, and ignore other values our polity considers important. We shall explore each of these criticisms again by reference to the decisions in Weber and Griffin. We conclude our analysis of textualism by discussing Bob Jones University v. United States, ${ }^{75}$ a decision in which the Court broke with textualism to pursue other important social values.

Textualism can control statutory interpretation only if the text itself offers a complete and reasonably determinate source of meaning. This proposition has long been contested, and it is more controversial than ever today. Whether or not language itself is intrinsically indeterminate, one would have to concede that general, politicized terms such as "discrimination" are susceptible of different interpretations. ${ }^{76}$ The statute in Weber makes it an unlawful practice for an employer or union "to discriminate against any individual because of his race." The dissenting opinion chided the Court for ignoring the "plain language" of the statute. ${ }^{77}$ Yet this criticism presupposes that "discrimination" means "any differentiation based upon race." That is one definition of "discrimination," but not the only one. "Discrimination" can also mean a "differentiation because of an invidious reason," and indeed the Supreme Court itself has found intentional invidious conduct to be a significant component of discrimination in other circumstances. ${ }^{78}$

(1899), reprnted in Oliver Wendell Holmes, Collected Legal Papers 203, 207 (1920). Nevertheless, Justice Holmes later wrote that when interpreting amendments of old statutory language, "the general purpose is a more important aid to the meaning than any rule which grammar or formal logic may lay down." United States v. Whitridge, 197 U.S. 135, 143 (1905). For a recent variation, see Frank H. Easterbrook, The Role of Original Intent in Stalutory Consiruction, 11 Harv. J.L. \& PUb. PoL'Y 59, 65 (1988) (we should replace the meaningless concept of legislative intent and "look at the statutory structure and hear the words as they would sound in the mind of a skilled, objectively reasonable user of words").

73. United States v. American Trucking Ass'ns, 310 U.S. 534, 543 (1940), followed and quoted $m$ Huffman v. Western Nuclear, Inc., 108 S. Ct. 2087, 2092 (1988).

74. Caminetti v. United States, 242 U.S. 470, 490 (1917).

75. 461 U.S. 574 (1983).

76. See Zechariah Chafee, Jr., The Disorderly Conduct of I'ords, 41 Colum. L. Rev. 381 (1941); Michael S. Moore, The Semantics of Judging. 54 S. CaL. L. REv. 151, 181-99 (1981).

77. "Were Congress to act today specifically to prohibit the type of racial discrimination suffered by Weber, it would be hard pressed to draft language better tailored to the task than that found in ... Title VII ..." V'eber, 443 U.S. at 226 (Rehnquist, J., dissenting). To the same effect is Johnson v. Transportation Agency, 480 U.S. 616, 670-71 (1987) (Scalia, J., dissenting).

78. Thus, the Court has found no fourteenth amendment "discrimination" when state conduct harming racial groups has not been "intentional" (read "invidious") and has only "resulted" in differentiation. See Washington v. Davis, 426 U.S. 229 (1976), followed in City of 
"Discrimination" has acquired nuances that are hard to capture. For example, in common usage we do not say we "discriminate" against peaches because we prefer pears (although this would arguably be a correct use of the word). Is it any more natural to say we are "discriminating" when we establish a program to try to rectify past misdeeds by hiring or training more people who have suffered invidious "discrimination" at our hands in the past?

Even those who agree with us that "discrimination" in Weber is not textually determinate might argue that the double wages statute in Grif$f i n$ is determinate, because it is more detailed and does not use terms that have a rich variety of connotations. But is that so? The statute says the owner "shall pay to the seaman a sum equal to two days' pay for each and every day during which payment is delayed beyond the respective periods." The statute does not explicitly provide that "there shall be no diminishment of such recovery of double wages for any reason whatsoever." Like statutes of limitations which employ similarly broad and mandatory terms, the penalty statute could be interpreted to permit judicial tolling of the double wage award, with no greater violence to the statutory language. In addition, a statutory prerequisite to recovery of the penalty in Griffin was the employer's failure to pay wages "without sufficient cause," delegate discretion to the court to toll the running of the penalty. ${ }^{80}$ Although the "plain meaning" of the statute lends support to the Court's interpretation in Griffin, it hardly requires it.

An additional problem with any strict textualist theory is its failure to consider that the meaning of text is strongly influenced by context. ${ }^{81}$ If we were to write you a note, "Go fetch us some meat," you could not interpret that note without knowing and understanding its context. ${ }^{82}$ This same sort of analysis is readily applicable to legal texts. When Congress told us in 1964 that we should not "discriminate" on the ba-

Mobile v. Bolden, 446 U.S. 55, 66-67 (1980); Village of Arlington Heights v. Metropolitan Hous. Dev. Corp., 429 U.S. 252 (1977).

79. The statute is quoted in the text accompanying note 64 supra.

80. See Griffin v. Oceanic Contractors, Inc., 458 U.S. 564, 580-84 (1982) (Stevens, J., dissenting).

81. "Words are not pebbles in alien juxtaposition; they have only a communal existence; and not only does the meaning of each interpenetrate the other, but all in their aggregate take their purport from the setting in which they were used ...." Shell Oil Co. v. Iowa Dep't of Revenue, 109 S. Ct. 278, 281 n.6 (1988) (quoting NLRB v. Federbush Co., 121 F.2d 954, 957 (2d Cir. 1941)); see Patricia M. Wald, Some Observations on the Use of Legislative History in the 1981 Supreme Court Term, 68 Iowa L. Rev. 195, 199 (1983).

82. Have you regularly been fetching us meat? If so, you might reasonably assume that we want the same sort of meat you have been bringing us heretofore. What is the purpose of this order for meat? If you know from prior context that we are having a fancy dinner party, you might bring us prime steaks. If you know the meat is for breakfast tomorrow morning, you might bring us bacon and sausage. What kind of meat do we like generally? If you know we despise red meat, you might bring us fowl, or perhaps even fish (which many people don't consider meat at all). And so on. See $2 \mathrm{H}$. HART \& A. SACKs, supra note 41, at 1146-47 (excerpting Francis Lieber, Legal and Political Hermeneutics 17-20 (2d ed. 1880)). 
sis of race in employment decisions, did we not know from ten years of experience with Brown, from the horrific pictures of Bull Connor's firehoses pummelling black youths marching against racism, from the March on Washington, and from Dr. Martin Luther King's eloquent speeches and letters, that the point of the statute was to seek justice for a group that had systematically been treated unjustly in our society? The thrust of the Court's opinion in Weber was that our country's commitment in Title VII was to results as well as process. In the context of racial injustice in this country, one lesson is that differentiation penalizing black Americans is not the same as differentiation seeking to redress patterns of prior prejudice and oppression.

A final problem undercuts textualism: the importance of the interpreter's own context, including current values. Philosophy and literary theory suggest to us that interpretation cannot aspire to universal objectivity, since the interpreter's perspective will always interact with the text and historical context. ${ }^{83}$ Had we been presented with the Weber issue in 1964, we might well have agreed that affirmative action was neither necessary nor proper under Title VII, for we might have been filled with hopeful expectation that Title VII would engender colorand sex-blind hiring decisions and would integrate blacks and other groups into the workforce. Fifteen years later, we would have voted to uphold the affirmative action arrangement in Weber, because we were less optimistic that patterns of discrimination could be eliminated in a short time by a color-blind approach. Some years from now, we might vote to curtail Weber, if we believe that affirmative action has outlived its usefulness and erected new and more subtle forms of racial barriers. ${ }^{84}$

The more general point, of course, is that current values cannot easily be excluded from statutory interpretation. ${ }^{85}$ Where current values and historical context strongly support an interpretation, a determinate text will not stand in the way. Consider the Bob Jones case. ${ }^{86}$ The issue was whether a nonprofit private school prescribing racially discriminatory admissions standards could qualify for exemption from federal income taxes. Section 501(c)(3) of the Internal Revenue Code provided an exemption for institutions "organized and operated exclusively for

83. The assertion in text is associated with the work of Gadamer, see note 5 supra, and Gadamer himself rested upon a rich tradition of hermeneutics and historiography. See Davin Couzens hoy, The Critical Circle: Literature, History, and Philosophical HermeneuTICS (1978); G. WARNKE, supra note 5, at 5-41.

84. This is an essential message of Justice Scalia's dissenting opinion in Johnson v. Transportation Agency, 480 U.S. 616 (1987), and may have inspired the Court's willingness in Wards Cove Packing Co. v. Atonio, 109 S. Ct. 2115 (1989), to deemphasize the importance of statistical disparities in employment discrimination lawsuits.

85. Eskridge, supra note 3, argues this point in greater detail and provides a range of examples from recent Supreme Court decisions. See also T. Alexander Aleinikoff, Updating Statulony Interpretation, 87 Mrch. L. Rev. 20 (1988); William N. Eskridge, Jr., Public l'alues in Slatutony Interpretation, 137 U. PA. L. REv. 1007 (1989).

86. Bob Jones Univ. v. United States, 461 U.S. 574 (1983). 
religious, charitable, . . or educational purposes."87 Although Bob Jones University was an "educational" institution falling within the literal terms of the statutory exemption, a nearly unanimous Supreme Court held that it did not qualify, based upon an expansively contextualist approach to the statute. Historically, the income tax exemption was for "charitable organizations" because they performed public services of value to society. 88 The historical purpose of the statute would be thwarted, the Court argued, if the exemption were extended to organizations that are not "charitable," in the sense that their activities are "contrary to a fundamental public policy." 89 To establish that Bob Jones's activities did not meet this fundamental test, the Court recounted the judicial, executive, and legislative pronouncements against racial segregation in the last thirty years. ${ }^{90}$ The Court spent almost no time analyzing the statutory text, apparently because it considered the contextual arguments so compelling. ${ }^{91}$

Bob Jones is but one example of the refusal of the Court to rely on textualism when contextual arguments strongly cut against the textual ones. ${ }^{92}$ Thus, for practical as well as theoretical reasons, textualism

87. 26 U.S.C. $\$ 501$ (c)(3) (1982). Section 170 of the Code, id. § 170(c)(2)(B), provides a parallel deduction for contributions to institutions "organized and operated exclusively for religious, charitable, ... or educational purposes."

88. Bob Jones, 461 U.S. at 587, 591-92.

89. Id. at 592 .

90. Id. at 592-96.

91. In fact, though, the statutory language in Bob Jones is less than crystal clear. A maxim of statutory interpretation, noscilur a sociis, suggests that sometimes light may be shed on the meaning of statutory words by the words surrounding them. See, e.g., W. Eskridge \& P. FRICKEX, supra note 1, at 639-40. In Bob Jones, the provision in question granted tax-exempt status to "[c]orporations, and any community chest, fund, or foundation, organized and operated exclusively for religious, charitable, scientific, testing for public safety, literary, or educational purposes, or to foster national or international amateur sports competition ..., or for the prevention of cruelty to children or animals ..." 26 U.S.C. $\S 501$ (c)(3) (1982). Read in the context of the surrounding words, "educational" may well take on the "public interest" glow that the majority in Bob Jones gave to it. Moreover, schools qualify under $\$ 501$ (c)(3) only if they are organized exclusively for educational purposes. This requirement seemingly mandates that the entity deciding $\$ 501$ (c)(3) status-that is, the IRS or the courts-must judge whether a school has any features that may be deemed noneducational or anti-educational. At all events, any literalist meaning cutting against the majority's interpretation cannot be seen as so strong as to overwhelm the enormous contextual and policy justifications supporting the majority's result.

Note that Chief Justice Burger, a stickler for textual analysis in other cases, see, e.g., Board of Governors of Fed. Reserve Sys. v. Dimension Fin. Corp., 474 U.S. 361 (1986), wrote the opinion for the Court. Only Justice Rehnquist dissented.

92. For other recent examples, see EEOC v. Commercial Office Prods. Co., $108 \mathrm{~S}$. Ct. 1666, 1671-74 (1988); Rose v. Rose, 481 U.S. 619, 625-34 (1987); see also id. at 636-40 (O'Connor, J., concurring); California Fed. Sav. \& Loan Ass'n v. Guerra, 479 U.S. 272, 284-86 (1987) (plurality opinion); Offshore Logistics, Inc. v. Tallentire, 477 U.S. 207 (1986); Midlantic Nat'l Bank v. New Jersey Dep't of Envtl. Protection, 474 U.S. 494, 505-06 (1986); Lowe v. SEC, 472 U.S. 181 (1985); Washington Metro. Area Transit Auth. v. Johnson, 467 U.S. 925 (1984); Dickman v. Commissioner, 465 U.S. 330, 344 (1984); Southland Corp. v. Keating, 465 U.S. 1 (1984); Bell v. United States, 462 U.S. 356 (1983). See also Wald, supra note 81, at 195 (citations omitted):

[A]lthough the Court still refers to the 'plain meaning' rule, the rule has effectively been laid to rest. No occasion for statutory construction now exists when the Court 
will not work as a foundational approach to statutory interpretation. We have, of course, come full circle. Intentionalism and purposivism work no better. It appears that foundationalism has failed. ${ }^{93}$

\section{A Positive Model of Practical Reasoning IN STATUTORY INTERPRETATION}

The analysis in Part I not only shows that the leading foundationalist theories are flawed, but it also suggests an alternative to these views of statutory interpretation. In what follows we build a positive descriptive theory of statutory interpretation from an analysis of the Court's actual practice in statutory interpretation cases, such as Weber, Griffin, and $B o b$ Jones, and from our interpretation of the pragmatic and hermeneutical traditions in philosophy. This positive theory only seeks to make sense out of the Court's practice in statutory interpretation, in ways that foundationalism cannot. We reserve for Part III our normative evaluation of the Court's practice.

Each type of problem with foundationalism that we identified in Part I suggests one facet of our positive theory. We argued above that the leading foundationalist theories cannot redeem their claim to follow from the very nature of majoritarian democracy, that they do not yield objective and determinate answers, and that they cannot convincingly exclude other values, including current values. Weber, Griffin, and Bob Jones illustrate our theoretical critique and suggest that the Supreme Court does not follow any one of the foundationalist theories. We now suggest that these observations form the basis for a positive theory which refuses to privilege intention, purpose or text as the sole touchstone of interpretation, but which both explains the Supreme Court's practice in statutory interpretation and, at the same time, reflects the insights of modern theories of interpretation.

First, statutory interpretation involves creative policymaking by judges and is not just the Court's figuring out the answer that was put "in" the statute by the enacting legislature. An essential insight of hermeneutics is that interpretation is a dynamic process, and that the interpreter is inescapably situated historically. "Every age has to understand a transmitted text in its own way," says Gadamer.

The real meaning of a text, as it speaks to the interpreter, does not depend on the contingencies of the author and whom he originally wrote for. It certainly is not identical with them, for it is always partly determined also by the historical situation of the interpreter and hence

will not look at the legislative history. When the plain meaning rhetoric is invoked, it becomes a device not for ignoring legislative history but for shifting onto legislative history the burden of proving that the words do not mean what they appear to say.

93. It goes without saying that the three theories discussed in the text do not exhaust the range of possible foundationalist theories. For the reasons expressed in Parts I and II, however, we doubt that any other foundationalist approach could be more successful. 
by the totality of the objective course of history. 94

Gadamer's primary metaphor for interpretation is a "fusion of horizons"95: The historical text contains assumptions and "preunderstandings"96_a "horizon"-which is often quite different from the "horizon" of the later interpreter. That is why interpretation is difficult and not mechanical. Because the horizons are alienated from one another, the interpreter can never completely recreate or understand the text's horizon. Yet that does not defeat interpretation, if it is viewed as an effort to seek common ground between the two often distant horizons. That common ground is always possible, Gadamer says, because the temporal gulf is filled with traditions and experience that inform our current horizon and link it with the previous one. ${ }^{97}$

Hermeneutics suggests that the text lacks meaning until it is interpreted. Given the importance of the interpretive horizon, which itself changes over time, interpretation must not "chase the phantom of an historical object."98 A text, then, is not meaningful "in itself," apart from possible interpreters and their historical contexts. Nor is it meaningful apart from the task of the interpreter. Gadamer argues, following Aristotle, that one does not "understand" a text in the abstract, without an "application" of the text to a specific problem.99 American pragmatism, also influenced by Aristotle, complements this hermeneutic insight. Reasoning in human affairs does not seek abstract answers, but concretely useful results. Theories of reasoning, for James, are simply "mental modes of adaptation to reality, rather than revelations or gnostic answers." 100

Consider Weber in this light. The interpretive process is creative, not mechanical. Viewed in the context of the complex goals of the Civil Rights Act and subsequent difficulties in implementation, making sense of the statute's command not to "discriminate" requires much more than finding a meaning for the term. Even if the interpretive process were viewed as retrieving the answer Congress would have reached in 1964 (had it deliberated on the issue), the inquiry involves "imagina-

94. H. Gadamer, Truth and Method, supra note 5, at 263. Gadamer explicitly ties this insight to judicial interpretation of statutes. See id. at 289-95.

95. Id. at 273. This central feature of Gadamerian hermeneutics is discussed more extensively in G. WARNKE, supra note 5, at 68-69, 103-04; J. WEINSHEIMER, supra note 5, at 15657, 183-84, 210-12.

96. "Preunderstandings" is our translation of Gadamer's phrase "Torurteil," which can also be translated as "prejudgment" or "prejudice." Our preunderstandings are the (usually) unconscious structures of thought and attitude that we bring to interpretation.

97. See H. GAdAMER, TRUTh AND METHOD, supra note 5, at 264-65:

Time is no longer primarily a gulf to be bridged .... It is not a yawning abyss, but is filled with the continuity of custom and tradition, in the light of which all that is handed down presents itself to us. Here it is not too much to speak of a genuine productivity of process.

98. Id. at 267.

99. Id. at 274-78, 289-305.

100. W. JAMEs, supra note 6 , at 194. 
tive" work by the judge. These lessons of Weber are consistent with the insights of modern literary theory, historiography, and philosophy: There is no interpretation without an interpreter, and the interpreter will interact with the text or historical event. Just as the interpreter learns from the text and history, so too does she speak to it. ${ }^{101}$ What was decisive in Weber, surely to Justice Blackmun and probably to other Justices in the majority as well, was what the interpreters learned about the statute from considering the facts of the case: More than a decade after the statute was enacted there were only 2 percent blacks in the craft workforce, contrasted with 39 percent blacks in the overall workforce.

Second, because this creation of statutory meaning is not a mechanical operation, it often involves the interpreter's choice among several competing answers. Although the interpreter's range of choices is somewhat constrained by the text, the statute's history, and the circumstances of its application, the actual choice will not be "objectively" determinable; interpretation will often depend upon political and other assumptions held by judges. Under Gadamer's fusion of horizons metaphor, interpretation seeks "to make the law concrete in each specific case," and " $[t]$ he creative supplementing of the law that is involved is a task that is reserved to the judge."102 As a practical matter, how could it be otherwise? Many statutes leave key terms ambiguous, often intentionally, ${ }^{103}$ and thereby delegate rulemaking authority to courts or agencies. ${ }^{104}$ Over time, these ambiguities and unanswered questions multiply, as society changes and background legal assumptions change with it. Hermeneutics suggests that as the interpreter's own background context-her "tradition"--changes, so too will her interpretive choices.

Consider Bob Jones in this light. The exemption for "charitable" institutions is a broad legislative message whose specific implementation has been left to the IRS. In the early twentieth century, when Plessy was still good law, it might have been appropriate to include segregated academies among the institutions that receive the exemption. But in the Brown era, our society's commitment to racial and ethnic integration put pressure on the IRS to rethink the application of the exemption to institutions that perpetuated segregation. The IRS for several years left in place an interpretation that allowed the exemption for such institutions. But the background tradition-and the political context-was

101. See H. Gadamer, Truth and Method, supra note 5 , at 330-41.

102. Id. at 294.

103. See, e.g., Business Elecs. Corp. v. Sharp Elecs. Corp., 108 S. Ct. 1515 (1988) (Sherman Act); $c$. R. POSNER, supra note 13, at 294-315 (at least half of federal courts' statutory interpretation cases involve statutes that are so broadly phrased as to leave most policy details to courts); Kousser, supra note 30, at 361-63.

104. See, e.g., Chevron, U.S.A., Inc. v. Natural Resources Defense Council, 467 U.S. 837 (1984); see also Edward Rubin, Law and Legislation in the Administrative State, 89 Colum. L. Rev. 369 (1989). 
changing dramatically in that period, and those changes eventually impelled the IRS to change its position in 1970 and 1971. When the Supreme Court sustained that decision in Bob Jones, it too was making a practical judgment-that the national policy against racial discrimination outweighs the reliance interests built around the earlier interpretation, and that the political system had acquiesced in the new IRS position. There are good arguments against this interpretation of the statute in Bob Jones, and many of them are set forth in Justice Rehnquist's dissenting opinion. But, as Justice Powell suggested in his concurring opinion, ${ }^{105}$ the Court's political judgment was a defensible one, even if not the inevitable one. One's view of the correctness of the Court's decision is strongly influenced by one's views about the breadth of Brown, the deference courts should show to the agency, and other political preunderstandings. However one votes in a case like Bob Jones, one is making a political choice, or, more accurately, a cluster of choices.

Third, when statutory interpreters make these choices, they are normally not driven by any single value-adhering to majoritarian commands or encouraging private reliance on statutory texts or finding the best answer according to modern policy-but are instead driven by multiple values. Both hermeneutics and pragmatism emphasize the complex nature of human reasoning. When solving a problem, we tend to test different solutions, evaluating each against a range of values and beliefs we hold as important. The pragmatistic idea that captures this concept is the "web of beliefs" metaphor. ${ }^{106}$ We all accept a number of different values and propositions that, taken together, constitute a web of intertwined beliefs about, for example, the role of statutes in our public law. Each of us may accord different weight to the specific values, but almost no one excludes any of the important values altogether. Decisionmaking is, therefore, polycentric, and thus cannot be linear and purely deductive. Instead, it is spiral and inductive: We consider the consistency of the evidence for each value before reaching a final decision, and even then check our decision against the values we esteem the most. Given this web of beliefs and the spiral form of decisionmaking, an individual's reasoning will depend very much on the context of the case at hand, and specifically on the relative strength of each consideration.

Consider Griffin from the perspective of the web metaphor. A Justice who is a thoroughgoing textualist would surely agree with the Griffin result, given the relative clarity of the statutory language. But so could an intentionalist Justice: Although there is no smoking gun in the legislative history, the legislative context and the strong statutory

105. See Bob Jones, 461 U.S. at 606-12 (Powell, J., concurring in part and concurring in the judgment).

106. Sce generally Steven J. Burton, An Introduction to Law and Legal Reasoning 132-36 (1985); W.V. Quine \& J.S. Ullian, The Web of Belief (1970). 
language suggest that Congress would probably have favored substantial punitive sanctions had it addressed the issue. And so could a purposivist Justice, because surely one major purpose of the statute was to deter employer misconduct, which the $\$ 302,000$ award in Griffin would seem to do. Even a Justice concerned only with fair results might applaud the Griffin result. In fact, seven Justices of differing jurisprudential stripes formed the majority in Griffin, and Justice Rehnquist's opinion justified the result by arguing from the relatively clear statutory language, ${ }^{107}$ the original legislative intent, ${ }^{108}$ the overall statutory purpose, ${ }^{109}$ and (to some extent) the reasonableness of the interpretation. ${ }^{110}$ Whether ultimately correct, the opinion in Griffin, by its strategy of cumulative assessment and weighing of factors potentially relevant to interpretation, seems more persuasive than would any foundationalist avenue to the same result. 111

To illustrate the web metaphor in more detail, consider some variations on Griffin, and the potential response of Justices who sometimes seem to adopt foundationalist approaches. Justice Brennan, the author of Weber, might tentatively be identified as emphasizing dynamic purposivist analysis in his opinions. ${ }^{112}$ Justice Rehnquist's Weber dissent and other opinions ${ }^{113}$ suggest that he normally emphasizes inten-

107. See Griffin, 458 U.S. at 570-71 ("[t]he words chosen by Congress, given their plain meaning, leave no room for the exercise of discretion" about the running of the penalty period).

108. See id. at 570-74. Justice Rehnquist created a presumption about legislative intent based on the clear statutory language: "Our task is to give effect to the will of Congress, and where its will has been expressed in reasonably plain terms, 'that language must ordinarily be regarded as conclusive." "Id. at 570 (quoting Consumer Prod. Safety Comm'n v. GTE Sylvania, Inc., 447 U.S. 102, 108 (1980)). He then analyzed the legislative history and concluded that it supported this assessment about congressional intent. See id. at 572-74.

109. Based on statutory language, legislative history, and statutory background, Justice Rehnquist concluded that "although the sure purpose of the statute is remedial, Congress has chosen to secure that purpose through the use of potentially punitive sanctions designed to deter negligent or arbitrary delays in payment." Id. at 572.

110. In response to the argument that the Court's interpretation was absurd and unjust, and therefore could not have been intended by Congress, Justice Rehnquist asserted that the interpretation furthered the protective purposes of the statute. He also stated, in essence, that any unfairness in the result was for Congress, not the courts, to remedy. See id. at 574-76. In fact, although Justice Rehnquist did not note it, there is a good argument supporting the reasonableness of the result in Griffin, which is discussed in text accompanying notes 63-70 supra.

111. We would disagree, then, with any reading of Griffin that attributes to it a rigid foundationalist approach of textualism. Only parts of the opinion have that flavor, and we agree with the outcome in the case despite our non-textualist orientation. At most, the opinion may unduly stress the importance of the statutory language, but even then the opinion sees the language as important at three levels (textualist, intentionalist, and purposivist).

112. See, e.g., Mississippi Band of Choctaw Indians v. Holyfield, 109 S. Ct. 1597 (1989); Houston v. Lack, 108 S. Ct. 2379, $2382-83$ (1988); K Mart Corp. v. Cartier, Inc., 108 S. Ct. $1811,1819-31$ (1988) (Brennan, J., concurring in part and dissenting in part); Johnson v. Transportation Agency, 480 U.S. 616 (1987); School Bd. v. Arline, 480 U.S. 273 (1987); Local 28, Sheet Metal Workers v. EEOC, 478 U.S. 421 (1986) (Brennan, J.) (plurality opinion).

113. See, e.g., Argentine Republic v. Amerada Hess Shipping Corp., 109 S. Ct. 683 (1989); Bourjaily v. United States, 483 U.S. 171 (1987); Dames \& Moore v. Regan, 453 U.S. 654 (1981); Leo Sheep Co. v. United States, 440 U.S. 668 (1979). 
tionalist considerations. Both joined the opinion in Griffin, which made a fairly good case for consistency with the values of textualism, intentionalism, purposivism, and current policy. Now assume that the statutory text is quite clear, but the result is somewhat at odds with the statute's overall purpose (which we narrow to that of compensating the seaman). Chief Justice Rehnquist would still vote for a bonus recovery: Assuming the legislative history is neutral, he would follow the text because it is the best available evidence of legislative intent, and because its other values (predictability and reliance) appeal to the Chief Justice more than the dynamic policy values of purposivism. At first blush, we might expect Justice Brennan to dissent, based upon a Weber analysis. But upon closer examination, we think Justice Brennan would probably still support the Griffin result. To begin with, Justice Brennan would consider the strength of the evidence of legislative purpose and the clarity of the statute's language. If the statute is clear and the purpose is debatable, it is unlikely that Justice Brennan would favor the latter. Although he would vote to bend the language of a "clear" statute to serve compelling public purposes (Bob Jones), Justice Brennan seems to accept the values of textualism with enough enthusiasm to bow to the clear text of Griffin-especially since the ultimate result, a large recovery against a shipowner who apparently behaved squalidly, seems quite fair. ${ }^{114}$

Next assume that the statutory text in Griffin is truly ambiguous, that the statute clearly indicates that its purpose is to penalize bad faith discharges without pay, but that some legislative history suggests that courts should not enter draconian recoveries. Justice Brennan would still probably endorse the Grifin result. Chief Justice Rehnquist's position is not so clear, for it depends on the strength of the legislative history. If he finds a detailed history which clearly endorses limits on recovery or strongly assumes such limits, he will dissent, as he did in Weber. But if, as is more likely, the legislative history is sparse and contains only a few isolated statements to that effect, the Chief Justice may well vote with Justice Brennan. He will take comfort in the formal codification of the statutory purpose and, probably, also in the fairness of penalizing the shipowner under these circumstances. ${ }^{115}$

In addition to the web of beliefs idea, two other metaphors, one drawn from the pragmatist tradition and one drawn from the herme-

114. Justice Brennan has sometimes even adopted a textualist perspective-contra Weber-in cases where a clear text supports a result at odds with contextual evidence and policy considerations. See, e.g., Mallard v. United States Dist. Court for the S. Dist. of Iowa, 109 S. Ct. 1814 (1989); Communications Workers v. Beck, 108 S. Ct. 2641 (1988); Honig v. Doe, 484 U.S. 305, 308 (1988); International Paper Co. v. Ouellette, 479 U.S. 481, 500 (1987) (Brennan, J., dissenting).

115. Chief Justice Rehnquist will sometimes disregard text or legislative history (but not both) to reach results supported by current policy or fairness. See, e.g., United States Dep't of Justice v. Julian, 486 U.S. 1 (1988); Jersey Shore State Bank v. United States, 479 U.S. 442 (1987); Ansonia Bd. of Educ. v. Philbrook, 479 U.S. 60 (1987). 
neutical tradition, suggest more precisely how a practical reasoning approach would work. First, consider Peirce's contrast of the chain and the cable. ${ }^{116} \mathrm{~A}$ chain is no stronger than its weakest link, because if any of the singly connected links should break, so too will the chain. In contrast, a cable's strength relies not on that of individual threads, but upon their cumulative strength as they are woven together. Legal arguments are often constructed as chains, but they tend to be more successful when they are cable-like. The Court's opinion in Grifin draws its strength from this phenomenon: The text, one probable purpose, some legislative history, and current policy each lend some-even if not unequivocal-support to the result. Each thread standing alone is subject to quarrel and objection; woven together, the threads persuaded both Justice Rehnquist and Justice Brennan, a not unimpressive achievement.

In many cases of statutory interpretation, of course, the threads will not all run in the same direction. The cable metaphor suggests that in these cases the result will depend upon the strongest overall combination of threads. That, in turn, depends on which values the decisionmakers find most important, and on the strength of the arguments invoking each value. For most of the Supreme Court Justices, a persuasive textual argument is a stronger thread than an otherwise equally persuasive current policy or fairness argument, because of the reliance and legislative supremacy values implicated in following the clear statutory text. ${ }^{117}$ And a clear and convincing textual argument obviously counts more than one beclouded with doubts and ambiguities.

Our model of practical reasoning in statutory interpretation is still not complete, for it lacks a dynamic element that is intrinsic to human reasoning in general, and interpretation in particular. The various arguments (the threads of our cable) do not exist in isolation; they interact with one another. A final metaphor that captures this interaction is the "hermeneutical circle": A part can only be understood in the context of the whole, and the whole cannot be understood without analyzing its various parts. ${ }^{118}$ To interpret the statute in Griffin, for example, the interpreter will look at the text and the legislative history and the purpose and current values. But to evaluate the text, the interpreter will consider it in light of the whole enterprise, including the history,

116. Peirce suggested that philosophy ought "to trust rather to the multitude and variety of its arguments than to the conclusiveness of any one. Its reasoning should not form a chain which is no stronger than its weakest link, but a cable whose fibers may be ever so slender, provided they are sufficiently numerous and intimately connected." C.S. PEIRCE, 5 Collected Papers, supra note 6, para. 264.

117. Here, as throughout Part II, we are working from the Court's practice. The preference for textual arguments over fairness arguments is itself a political choice the current Court makes. We think the opposite choice-a good fairness argument is better than a good textual one-is also politically defensible.

118. See generally' H. Gadamer, Truth and Method, supra note 5, at 235-40, 258-67; Martin Heidegger, Being and Time 194-95 (J. Macquarrie \& E. Robinson trans. 1962); D. HoY, supra note 83 . 
purpose, and current values. In other words, none of the interpretive threads can be viewed in isolation, and each will be evaluated in its relation to the other threads.

Following Heidegger, Gadamer deploys the hermeneutical circle in a particularly interesting way, which roughly captures the dynamics of legal interpretation. ${ }^{119}$ Because we always approach texts from the perspective of our own historically situated horizon, we tend to project our "preunderstandings" onto the text, viewed as a whole. That is essential to interpretation, because the preunderstandings are conditioned by tradition and, hence, help us link our horizon with that of the text. But the hermeneutical circle suggests that a true dialogue with the text requires the interpreter to reconsider her preunderstandings as she considers the specific evidence in the case, and then to formulate a new understanding, which in turn is subject to reconsideration. For Gadamer, the essential lesson of the circle metaphor is the hermeneutical attitude: "[A] person trying to understand a text is prepared for it to tell him something."120 The "to and fro movement" involved in the hermeneutical circle is not just the interpreter's movement from a general view of the statute to the specific evidence and back again; rather, it requires her to test different understandings of the text in an ongoing effort to determine its proper interpretation.

The positive metaphors of our analysis-the web of beliefs idea, the cable-versus-chain contrast, and the hermeneutical circle-suggest the contours of a practical reasoning model of statutory interpretation that roughly captures the Court's practice. Our model holds that an interpreter will look at a broad range of evidence-text, historical evidence, and the text's evolution-and thus form a preliminary view of the statute. The interpreter then develòps that preliminary view by testing various possible interpretations against the multiple criteria of fidelity to the text, historical accuracy, and conformity to contemporary circumstances and values. Each criterion is relevant, yet none necessarily trumps the others. Thus while an apparently clear text, for example, will create insuperable doubts for a contrary interpretation if the other evidence reinforces it (Griffin), an apparently clear text may yield if other considerations cut against it (Bob Jones and Weber). As the interpreter comes to accept an interpretation (perhaps a confirmation of her preliminary view), she considers a congeries of supporting arguments, which may buttress her view much "like the legs of a chair and unlike the links of a chain."121

119. See H. Gadamer, Truth and Method, supra note 5, at 235-40, 261-67.

120. Id. at 238. "All that is asked is that we remain open to the meaning of the other person or of the text. But this openness always includes our placing the other meaning in a relation with the whole of our own meanings or ourselves in a relation to it." Id.

121. Robert Summers, Instrumentalism and American Legal Theory 156 (1982). 
This dialectical method of statutory interpretation, which is familiar to us all, ${ }^{122}$ can be schematized as follows:

\section{A Practical Reasoning Model of Statutory Interpretation}

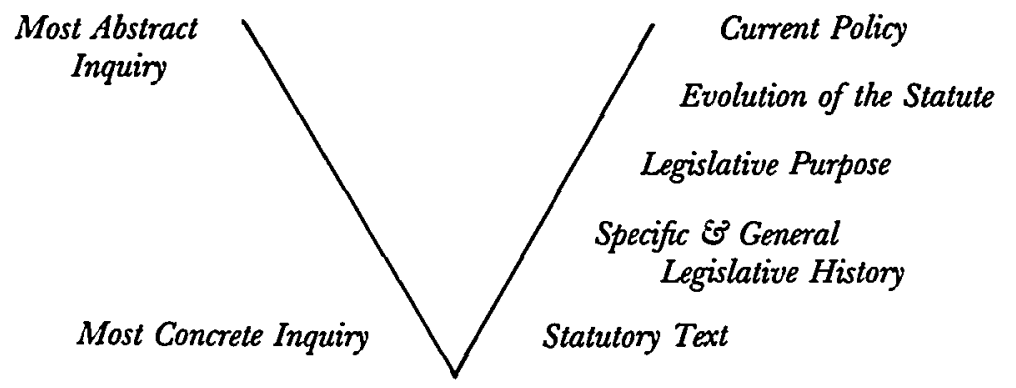

As explained below, this model identifies the primary evidentiary inquiries in which the Court will engage. ${ }^{123}$ The model is, in crude imagery, a "funnel of abstraction." It is funnel-shaped for three reasons. First, the model suggests the hierarchy of sources that the Court has in fact assumed. For example, in formulating her preunderstanding of the statute and in testing it, the interpreter will value more highly a good argument based on the statutory text than a conflicting and equally strong argument based upon the statutory purpose. Second, the model suggests the degree of abstraction at each

122. See Farber \& Frickey, Praclical Reason, supra note 3, at 1639-56 and sources discussed therein; $c f$. Posner, Skeplicism, supra note 3 (thoughtful assessment of practical reason and conventionalism in legal justification). As Frank Michelman has said:

Situated practical judgment seems always to involve a combination of something general with something specific, endorsement of both a general standard and a specific application, or of both a general value and a specific means to its effectuation. Judgment mediates between the general standard and the specific case. In order to apply the standard in the particular context before us, we must interpret the standard. Every interpretation is a reconstruction of our sense of the standard's meaning and rightness. This process, in which the meaning of the rule emerges, develops, and changes in the course of applying it to cases is one that every common law practitioner will immediately recognize.

Frank I. Michelman, The Supreme Court, 1985 Tenn-Foreword: Traces of Self-Government, 100 HARV. L. REv. 4, 28-29 (1986) (footnote omitted).

123. Apart from Griffn, other important Supreme Court opinions inspiring our funnel include Price Waterhouse v. Hopkins, 109 S. Ct. 1775, 1796 (1989) (O'Connor, J., concurring in the judgment); Davis v. Michigan Dep't of Treasury, 109 S. Ct. 1500 (1989) (Kennedy, J.); United States Dep't of Justice v. Reporters Comm. for Freedom of the Press, 109 S. Ct. 1468 (1989) (Stevens, J.); Beech Aircraft Corp. v. Rainey, 109 S. Ct. 439 (1988) (Brennan, J.) United States v. Wells Fargo Bank, 108 S. Ct. 1179 (1988) (Brennan, J.); Rose v. Rose, 481 U.S. 619 (1987) (Marshall, J.); id. at 636 (O'Connor, J., concurring in judgment); INS v. Cardoza-Fonseca, 480 U.S. 421 (1987) (Stevens, J.); Offshore Logistics, Inc. v. Tallentire, 477 U.S. 207 (1986) (O'Connor, J.); Midlantic Nat'l Bank v. New Jersey Dep't of Envtl. Prot., 474 U.S. 494 (1986) (Powell, J.); Dowling v. United States, 473 U.S. 207 (1985) (Blackmun, J.); Alexander v. Choate, 469 U.S. 287 (1985) (Marshall, J.); Dickman v. Commissioner, 465 U.S. 330 (1984) (Burger, C.J.); Watt v. Western Nuclear, Inc., 462 U.S. 36 (1983) (excellent debate between Marshall, J., for the Court, and Powell, J., dissenting); Jefferson County Pharmaceutical Ass'n v. Abbott Labs., 460 U.S. 150 (1983) (Powell, J.); American Soc'y of 
source. The sources at the bottom of the diagram involve more focused, concrete inquiries, typically with a more limited range of arguments. As the interpreter moves up the diagram, a broader range of arguments is available, partly because the inquiry is less concrete. Third, the model illustrates the pragmatistic and hermeneutical insights explained above: In formulating and testing her understanding of the statute, the interpreter will move up and down the diagram, evaluating and comparing the different considerations represented by each source of argumentation. In what follows, we explain those various considerations in greater detail.

\section{A. Textual Considerations}

Our practical reasoning model starts with the prevailing Supreme Court assumption that the statutory text is the most authoritative interpretive criterion. The text is most often the starting point for interpretation, and textual arguments carry the greatest argumentative weight. The Court's normative preference for text is a recognition of several values. Formally, all that is enacted into law is the statutory text, and at the very least legislative supremacy means that an interpreter must be attentive to the text. Functionally, citizens and lawmakers will rely on the apparent meaning of statutory texts. Textual primacy can also be a useful concrete limit on judicial power.

Textual analysis starts with the specific words of the statutory provi-

Mechanical Eng'rs, Inc. v. Hydrolevel Corp., 456 U.S. 505 (1982) (Blackmun, J.); American Tobacco Co. v. Patterson, 456 U.S. 63 (1982) (excellent debate between White, J., for the Court, and Brennan \& Stevens, J.J, dissenting); Dames \& Moore v. Regan, 453 U.S. 654 (1981) (Rehnquist, J.); St. Martin Evangelical Lutheran Church v. South Dakota, 451 U.S. 772 (1981) (Stevens, J., concurring); Potomac Elec. Power Co. v. Director, Office of Workers' Comp. Programs, 449 U.S. 268 (1980) (excellent debate between Stevens, J., for the Court, and Blackmun, J., dissenting); Industrial Union Dep't v. American Petroleum Inst., 448 U.S. 607 (1980) (Stevens, J.) (plurality opinion); Andrus v. Shell Oil Co., 446 U.S. 657 (1980) (Burger, C.J.); NLRB v. Yeshiva Univ., 444 U.S. 672 (1980) (Powell, J.); United Steelworkers v. Weber, 443 U.S. 193, 209-16 (1979) (Blackmun, J., concurring); Cannon v. University of Chicago, 441 U.S. 677 (1979) (Stevens, J.); Group Life \& Health Ins. Co. v. Royal Drug Co., 440 U.S. 205 (1979) (Stewart, J.); United States v. United States Gypsum Co., 438 U.S. 422 (1978) (Burger, C.J.); Regents of the Univ. of Cal. v. Bakke, 438 U.S. 265, 324-50 (1978) (Brennan, J., concurring in part and dissenting in part); Monell v. Dep't of Social Servs., 436 U.S. 658 (1978) (Brennan, J., for the Court, and Powell, J., concurring); United States v. Board of Comm'rs, 435 U.S. 110 (1978) (Brennan, J.); General Elec. Co. v. Gilbert, 429 U.S. 125 (1976) (excellent debate between Rehnquist, J., for the Court, and Brennan, J., dissenting); McDonald v. Santa Fe Trail Transp. Co., 427 U.S. 273 (1976) (Marshall, J.); Franks v. Bowman Transp. Co., 424 U.S. 747 (1976) (Brennan, J.); Albemarle Paper Co. v. Moody, 422 U.S. 405 (1975) (Stewart, J.); Connell Constr. Corp. v. Plumbers \& Steamfitters Local 100, 421 U.S. 616 (1975) (Powell, J.); United States v. Bisceglia, 420 U.S. 141 (1975) (Burger, C.J.); Bangor Punta Operations, Inc. v. Bangor \& Aroostook R.R., 417 U.S. 703 (1974) (excellent debate between Powell, J., for the Court, and Marshall, J., dissenting); CBS v. Democratic Nat'l Comm., 412 U.S. 94 (1973) (Burger, C.J.); Mitchum v. Foster, 407 U.S. 225 (1972) (Stewart, J.); Allied Chem. \& Alkali Workers v. Pittsburgh Plate Glass Co., 404 U.S. 157 (1971) (Brennan, J.); United States v. Thirty-Seven Photographs, 402 U.S. 363 (1971) (White, J.) (plurality opinion); Griggs v. Duke Power Co., 401 U.S. 424 (1971) (Burger, C.J.); Younger v. Harris, 401 U.S. 37 (1971) (Black, J.); Gutknecht v. United States, 396 U.S. 295 (1970) (Douglas, J.); Zuber v. Allen, 396 U.S. 168 (1969) (Harlan, J.). 
sion being interpreted. The interpreter should approach the statutory text as a reasonably intelligent reader would and give the text its most commonsensical reading. ${ }^{124}$ That reading should be sensitive to any special senses the words have acquired, and should also consider the placement of words in the sentence, and even the punctuation of the sentence. ${ }^{125}$ Textual analysis should further consider how the statutory provision at issue coheres with the general structure of the statute, since other provisions in the statute might shed light on the one being interpreted. For example, the Weber opinion and dissent both focused on section 703(j), a related provision of Title VII that limited the ability of the statute to "require" affirmative action. ${ }^{126}$ In such instances, the Court asks: Assuming that the statute should be read to make sense as an integrated text, which interpretation best "fits" into the "whole statute"? ${ }^{127}$ Indeed, the Court will sometimes look to similar provisions in other statutes, especially those regulating similar things. Have the words of the instant statute acquired a conventional meaning that we ought to accept? ${ }^{128}$

These are just the main lines of textual inquiry, and they suggest that in a great many cases several different interpretations may be textually justifiable. We believe Weber is such a case. While the Court sometimes says that the discovery of a plain meaning ends the interpretive inquiry, ${ }^{129}$ the Court's actual practice suggests that this is not usually the case, as Griffin and Bob Jones illustrate. ${ }^{130}$ These cases suggest

124. A qualification is in order here. Highly technical statutes should not be read with the "common sense" of the average person, but rather with the "common sense" of the special audience to which the statute is addressed (such as gas and oil companies or tax lawyers).

125. See, e.g., United States v. Ron Pair Enters., 109 S. Ct. 1026, 1030-31 (1989); United Sav. Ass'n of Texas v. Timbers of Inwood Forest Assocs., 484 U.S. 365 (1988); San Francisco Arts \& Athletics, Inc. v. United States Olympic Comm., 483 U.S. 522, 528-29 (1987); Lukhard v. Reed, 481 U.S. 368 (1987).

126. See 443 U.S. at 205-07 (Brennan, J., for the Court); id. at 244-47 (Rehnquist, J., dissenting).

127. See, e.g., Argentine Republic v. Amerada Hess Shipping Corp., 109 S. Ct. 683 (1989); Mackey v. Lanier Collections Agency \& Serv., Inc., 108 S. Ct. 2182 (1988); Bethesda Hosp. Ass'n v. Bowen, 485 U.S. 399 (1988); United Sav. Ass'n of Texas v. Timbers of Inwood Forest Assocs., 484 U.S. 365 (1988); Gwaltney of Smithfield v. Chesapeake Bay Found., 484 U.S. 49 (1987).

128. See, e.g., TWA v. Independent Fed'n of Flight Attendants, 109 S. Ct. 1225 (1989); Kungys v. United States, 108 S. Ct. 1537, 1546 (1988).

129. "Judicial perception that a particular result would be unreasonable may enter into the construction of ambiguous provisions, but cannot justify disregard of what Congress has plainly and intentionally provided." Commissioner v. Asphalt Prods. Co., 482 U.S. 117, 121 (1987) (per curiam). See, e.g., United States v. Providence Journal Co., 108 S. Ct. 1502 (1988) (Blackmun, J., for the Court); see also id. at 1511 (Scalia, J., concurring); Burlington N. R.R. v. Oklahoma Tax Comm'n, 481 U.S. 454, 461 (1987); United States v. Locke, 471 U.S. 84, 95-96 (1985). Note that even when the Court invokes the plain meaning rule, it will still usually look at the legislative history. See, e.g., Amoco Prod. Co. v. Village of Gambell, Alaska, 480 U.S. 531 (1987); INS v. Hector, 479 U.S. 85 (1986).

130. See also Edward J. DeBartolo Corp. v. Florida Gulf Coast Bldg. \& Constr. Trades Council, 108 S. Ct. 1392, 1397 (1988) (where otherwise acceptable construction would cause constitutional problems, the Court will construe to avoid them); United States v. Wells Fargo Bank, 108 S. Ct. 1179, 1183-84 (1988) (exemption from "all taxation" held to be only exemp- 
that a clear textual meaning merely establishes a presumption that the interpretation is correct. Usually that presumption will hold up upon examination of other factors in the model, as it did in Griffin. Sometimes, though, the other factors will strongly cut against the apparent meaning of the text, as in Bob Jones. If that occurs, the interpreter might reevaluate her belief that the text is really all that clear and, in any event, might be willing to override plain meaning to subserve the other important values involved in statutory interpretation.

\section{B. Historical Considerations}

In accordance with the Court's practice, our practical reasoning model also considers the original expectations of the Congress that enacted the statute. Original legislative expectations are important in a democracy where the legislature is the primary source of lawmaking. Evidence of the statute's background, together with the text, at least suggests the original meaning of the statute. To the extent that the Court can recover that original meaning, it subserves democratic values by enforcing the law as the legislature understood it, thus limiting judicial discretion and power. Moreover, citizens and policymakers often rely on these original expectations, especially when they reflect careful compromises. Historical considerations are more abstract and less authoritative than textual evidence, however, for the reasons suggested in Part I: The expectations and intentions of a large collection of people, acting some time ago, are difficult to discover, and reliance on these expectations is neither as reasonable nor as likely as reliance upon a statute's text.

The most authoritative historical evidence is the legislative history of the statute, because it is a contemporary record made by the enacting legislators. In some instances, the legislative history may provide an example or suggest an application that squarely fits a subsequent interpretive problem. Crystal-clear legislative history on an interpretive issue (a "smoking gun") is rare-and sometimes suspect, for it may be the result of strategic behavior. If it is available, however, and if it reinforces the apparent meaning of statutory language, that will probably be decisive in most cases ${ }^{131}$-indeed, such cases would usually not be worth litigating. On the other hand, clear legislative history will not be decisive if the statutory text is genuinely ambiguous, or if it supports the opposite interpretation. In such cases, the clarity of the legislative

tion from direct taxation); Kelly v. Robinson, 479 U.S. 36, 43 (1986) (Court looked to history of bankruptcy court deference to criminal judgments); Offshore Logistics, Inc. v. Tallentire, 477 U.S. 207, 223 (1986) (after discovering "natural meaning" of statutory language, Court continued to analyze legislative history and purposes); and cases cited in note 92 supra.

131. "[I]f an intent clearly expressed in committee reports is within the permissible limits of the [statutory] language and no construction manifestly more reasonable suggests itself, a court does pretty well to read the statute to mean what the few legislators having the greatest concern with it said it meant to them." HenRY J. Friendiy, Mr. Justice Frankfurter and the Reading of Statutes, in BENCHMARKS 216 (1967). 
history may be only illusory, or else trumped up to skew the interpretive process. ${ }^{132}$ This precept reflects the second-best status of legislative history as an interpretive guide. Unlike the statutory text, it was not enacted into law, and giving conclusive effect to clear legislative history when statutory language is ambiguous or vague is in tension with Article I requirements. It also may threaten to promote rent-seeking by private interests, who will often find it easier to insert evidence of private-interest deals in the legislative history than in the statutory language, thus making it less likely that the legislature will recognize and fight against the deal in the legislative arena. ${ }^{133}$ Thus, even crystalclear legislative history will not always control interpretation, and in any event other potential interpretive sources will be considered.

The interpreter will also consider Judge Posner's more general technique of imaginative reconstruction. ${ }^{134}$ There are two potential inquiries. When no specific legislative history addresses an issue, the interpreter will, with Judge Posner, ask what the enacting legislature, lacking foresight of the future, probably would have thought about the issue before the Court. Relevant evidence would include common law rules when the statute was enacted, general assumptions of law held by the enacting Congress, and contemporary statutes enacted on related subjects. ${ }^{135}$ Another, more subtle, way of posing the question is to ask what the legislature would have done had it possessed the foresight to anticipate what has actually happened since the statute was enacted. Both approaches may be necessary to pay due respect to the enacting legislature. The first inquiry is simply a second-best surrogate for missing specific legislative intent. The second inquiry, which the interpreter should perform whether or not she can discern either a specific or hypothetical original intent, recognizes that statutory enactment is part of the ongoing process of public law, not a static, isolated act. By changing existing law or making new law, an enacting legislature admits by its very act that law must sometimes be altered to meet changing conditions; it would be unreasonable to assume that legislators intended to cast their original understanding in stone. As time passes after the statutory enactment, we think this first inquiry deserves less, and the sec-

132. For an instance in which such clear legislative history was rejected, apparently because of its suspect character, see Monterey Coal Co. v. Federal Mine Safety and Health Review Comm'n, 743 F.2d 589 (7th Cir. 1984) (committee chairman's report addressing specific point at issue was outweighed by the silence otherwise expressed on the matter).

133. See Macey, supra note 44.

134. See text accompanying note 31 supra.

135. For examples of imaginative reconstruction, see Smith v. Wade, 461 U.S. 30, 39-45, 66-84 (1983) (interesting debate between Justice Brennan, for the Court, and Justice Rehnquist, dissenting, over the common law punitive damages rule in 1871); Leo Sheep Co. v. United States, 440 U.S. 668 (1979) (thorough background analysis of railroad land grant statutes of the 1860s); Allison v. Liberty Sav., 695 F.2d 1086, 1091-93 (7th Cir. 1982) (Posner, J., dissenting from denial of rehearing en banc) (reconstructing what Congress would have decided); Fishgold v. Sullivan Drydock \& Repair Corp., 154 F.2d 785 (2d Cir. 1946) (L. Hand, J.), aff'd, 328 U.S. 275 (1946). 
ond inquiry more, weight. ${ }^{136}$

The next interpretive focus is legislative purpose, the legal process inquiry. The counterfactual assumptions underlying this approachthat statutes are conclusively presumed to be purposive acts, that legislators are reasonable people pursuing the public interest in reasonable fashion-make this approach too abstract to be a controlling theory of statutory interpretation. Recall the difficulty we had in figuring out the primary statutory purposes in Weber, Griffin, and Bob Jones. Yet these very assumptions, coupled with purposivism's focus upon statutory context, help locate statutes on the surrounding legal and social terrain, and enable them to evolve along with society and the social problem the statute originally addressed.

As traditional legal process thought employed it, purposivist analysis is inherently ambiguous. Obviously, the interpreter is interested in the original legislative purpose or purposes: What problem was Congress was trying to solve, and what general goals did it set forth in trying to solve it? Sometimes this inquiry is fairly determinate. Other times, as in Weber, Griffin, and Bob Jones, it is difficult, because several original purposes are apparent, and they push the interpreter in different directions. In these instances, the inquiry goes beyond the original purposes and asks, as the Court did in Weber, what purpose the interpreter should "attribute" to the statute. This attribution of purpose will inevitably be influenced by the interpreter's current context and the evolution of the statute over time.

\section{Evolutive Considerations}

Our final two inquiries, based upon the Court's practice, follow from the dynamic purpose analysis suggested above. These are highly abstract inquiries having less connection to text and legislative expectations, and hence less authority in a democracy. Yet these inquiries are pertinent, because the enactment of statutes is part of a dynamic process. ${ }^{137}$

136. This second version of imaginative reconstruction resembles the suggestion that an intentionalist approach should consider not only the interpretation's consistency with original legislative intent, but also its consequences. This is so because "[r]ational decisionmaking under uncertainty requires that we take those consequences into account in choosing between risky alternatives." Farber \& Frickey, Legislative Intent, supra note 3, at 462. By asking how the enacting legislature would answer the interpretive question if given knowledge of contemporary circumstances, the second variety of imaginative reconstruction allows statutes to evolve in light of how that legislature, and not simply the current Court, would probably evaluate the modern context. This focus helps differentiate the second version of imaginative reconstruction from other evolutive inquiries discussed in text accompanying notes 137-143 infra. The importance of the second version of imaginative reconstruction overtakes that of the first version as the statute ages, because the social circumstances the statute encounters become increasingly further removed from the original expectations of the enacting legislature.

137. Justice Frankfurter acknowledged at least some of the dynamic quality of statutory interpretation that we attempt to capture in our funnel of abstraction when he wrote that " $[t]$ he meaning of . . . a statute cannot be gained by confining inquiry within its four corners. Only the historic process of which such legislation is an incomplete fragment-that to which it 
The enactment of a statute is often the beginning of a significant process of implementation by courts or agencies. Implementation changes the statute, because the statute must be applied-and often subtly redirected-to meet variations of the problem not originally anticipated. For example, when it enacted Title VII, Congress assumed that outlawing color-conscious employment decisions would actually produce equal employment opportunities for blacks. The problem was not so easy to solve, however. Blacks continued to be underrepresented in the skilled workforce, at least partly because of covert discrimination and the ongoing effects of past discrimination. Thus the Court concluded in Weber that if the nation were to realize Title VII's goal of providing jobs for blacks, it would have to relax the requirement of color-blindness. Weber is therefore a clear example of a case in which the Court interprets a statute to take into account evolutive considerations, or social and legal circumstances not anticipated when the statute was enacted.

Finally, statutory interpretation will consider current values, such as ideas of fairness, related statutory policies, and (most important) constitutional values. In Bob Jones, where the plain meaning of the statutory text undercut the Court's interpretation and the historical evidence was ambiguous, the fact that constitutional values supported denying the tax exemption was crucial to the decision. ${ }^{138}$ All but the most ardent textualist will probably admit that even clear statutes should not be interpreted to reach "absurd results"; clear inconsistency with current values, we argue, is akin to absurdity. Consideration of these values has in fact exercised an important gravitational pull in statutory cases. ${ }^{139}$

gave rise as well as that which gave rise to it-can yield its true meaning." United States v. Monia, 317 U.S. 424, 432 (1943) (Frankfurter, J., dissenting). Similarly, J. Willard Hurst has said:

[Statutory] text derives its vitality in part from its past-from the prior state of the law and the shortcomings of that state of law. The text derives its vitality in part from its future-from what those charged with applying it do to give it force, not only to promote its objectives but to overcome contrivances to evade its mandates. The statutory text is central and commands deference. But to grasp the full reality of its impact we should see it as part of a flow of policy-making activity.

J. Hurst, supra note 9 , at 41 .

138. See Mayer G. Freed \& Daniel D. Polsby, Race, Religion \& Public Policy: Bob Jones University v. United States, 1983 SuP. CT. REv. 1.

139. Indeed, the Court uses the traditional canons of statutory interpretation to create policy presumptions. See generally W. Eskridge \& P. FrickeY, supra note 1, at 655-89; Eskridge, supra note 85; Cass Sunstein, Interpreting the Regulatory State, 103 Harv. L. REv. (1990) (forthcoming). For example, the rule of lenity indicates that doubts about the ambit of criminal statutes should be resolved against criminal liability. Other substantive canons of interpretation presume against statutory interpretations that create constitutional problems for the statute, derogate from traditional executive or judicial functions, invade local matters traditionally left to state regulation, violate international law and treaties, or penalize Native Americans. W. Eskridge \& P. FRICKEY, supra note 1, at 658-76.

The Court also adverts to a number of procedural canons of interpretation, under which judges must defer to other decisionmakers. The main example is the canon of deference to agency interpretations of their operative statutes. Thus, when a statute contemplates that the primary interpretive responsibility rests with an agency, the court must limit its judgment to 
This last statement might seem surprising, since traditional foundationalist theories have emphasized original intent and plain meaning, and tended to suppress current policy. Yet legal hermeneutics and pragmatism readily question whether it is possible for interpreters to avoid the influence of current concerns. If interpretation is (as Gadamer puts it) a "fusion of horizons," and one of the horizons is that of a present interpreter, then current policies and values will inevitably be important to the dialectic of interpretation. If human reasoning seeks (as James puts it) to ascertain the "cash value" of various answers, their practical value in solving today's problems, then current policies and values will naturally be considered. One of us has argued that evolutive concerns, especially current policies, are important to statutory interpretation. ${ }^{140}$ And, notwithstanding the rhetoric in some of its opinions, the Supreme Court seems to agree. Concurring opinions in Weber and Bob Jones openly announced reliance on then-current values, ${ }^{141}$ and the Court relies on current values and policies in a wide variety of other cases. ${ }^{142}$

While our practical reasoning model is a descriptive synthesis of recent Supreme Court decisions, a classic example of its method can be found in a very old case-Church of the Holy Trinity v. United States. ${ }^{143}$ The church had hired an English clergyman and agreed to provide for his transportation to the United States, in apparent violation of the plain language of the following federal criminal statute:

[I]t shall be unlawful for any person, company, partnership, or corpo-

whether the agency's interpretation is "unreasonable," not whether it is the same as the interpretation the Court itself would have reached.

140. See Eskridge, supra note 3; see also Robert E. Keeton, Venturing To Do Justice: Reforming Private Law 94-97 (1969); Aleinikoff, supra note 85, at 46.61; Farber \& Frickey, Legislative Intent, supra note 3; Robert A. Leflar, Statutory Construction: The Sound Law Approach, in Ruggero Aldisert, The Judicial Process 177-80 (1976).

141. See Bob Jones, 461 U.S. at 606-12 (Powell, J., concurring in part and concurring in the judgment); Weber, 443 U.S. at 209-16 (Blackmun, J., concurring).

142. See Eskridge, supra note 3. Most of the cases cited as inspirations for our descriptive model implicitly or explicitly consider evolutive arguments. See note 123 supra. For other recent examples, see Robertson v. Methow Valley Citizens Council, 109 S. Ct. 1835 (1989) (deferring to revised agency rules based on statutory purposes); Price Waterhouse v. Hopkins, 109 S. Ct. 1775, 1796-1806 (1989) (O'Connor, J., concurring in the judgment) (statute evolves to meet practical problems of proof); Cotton Petroleum Corp. v. New Mexico, 109 S. Ct. 1698, 1706-07 (1989) (evolving principles of intergovernmental tax immunity influence interpretation of statute); TWA v. Independent Fed'n of Flight Attendants, 109 S. Ct. 1225 (1989) (borrowing line of NLRA cases to update Railway Labor Act); City of Canton v. Harris, $109 \mathrm{~S}$. Ct. 1197 (1989) (developing policy from precedent, not from statute or its original history); Mesa v. California, 109 S. Ct. 959, 968-69 (1989) (dynamic use of policy canons of construction); Firestone Tire \& Rubber Co. v. Bruch, 109 S. Ct. 948, 954-56 (1989) (common law of trusts as basis for dynamic interpretation); Communications Workers v. Beck, $108 \mathrm{~S}$. Ct. 2641, 2648-53 (1989) (borrowing line of NLRA cases to update RLA); Business Elecs. Corp. v. Sharp Elecs. Corp., 108 S. Ct. 1515, 1523 (1988) (inherently dynamic nature of Sherman Act); Edward J. DeBartolo Corp. v. Florida Gulf Coast Bldg. \& Constr. Trades Council, 108 S. Ct. 1392 (1988) (updating statute to avoid first amendment problems); Forrester v. White, 108 S. Ct. 538 (1988) (common law, constitutional analogues, purpose analysis used to update statute).

143. 143 U.S. 457 (1892). 
ration, in any manner whatsoever, to prepay the transportation, or in any way assist or encourage the importation or migration of any alien or aliens, any foreigner or foreigners, into the United States, its Territories, or the District of Columbia, under contract or agreement, parol or special, express or implied, made previous to the importation or migration of such alien or aliens, foreigner or foreigners, to perform labor or service of any kind in the United States, its Territories, or the District of Columbia. ${ }^{144}$

The statutory prohibition against employment contracts facilitating immigration is very broad and filled with loophole-plugging language. Elsewhere the statute exempted specific occupations from the prohibition, and clergy were not among these occupations. ${ }^{145}$ Hence, the Court conceded, with some understatement, that the government's textual argument had "great force." 146 Yet the Court refused to rest its decision on the apparent meaning of the statutory text, instead evaluating the text against other evidence. The title of the statute and its legislative background suggested that the purpose of the statute was to limit the supply of "cheap, unskilled labor" into the United States. "It was never suggested that we had in this country a surplus of brain toilers," the Court remarked. ${ }^{147}$ Under these circumstances, excluding the Christian minister-a "brain toiler"-would not subserve the statutory purpose.

Yet Holy Trinity Church found the purposivist argument no more dispositive than the textual arguments. Instead, the Court examined other historical and current policy arguments to test its tentative conclusion that "brain toilers" were not within the statutory prohibition. First, the Court relied on specific legislative history. The House report supported the Court's attribution of purpose, and the Senate committee report suggested that it would have preferred that the law specify "manual labor" rather than "labor and service" as the object of the prohibition, had it not feared the bill's passage would be slowed by the amendment. ${ }^{148}$ The Court's analysis closed by invoking a current policy value. The government's literalist approach threatened the societal value of religious freedom - and the idea of the United States as a "Christian nation."149 Given the public interest in favor of religious freedom, the Court refused to attribute to Congress any intention to discourage immigration of Christian ministers into this country.

Holy Trinity Church is a classic critique of naive textualism. When generalized, the critique illustrates the operation of our practical rea-

144. Act of Feb. 26, 1885, ch. 164, § 1, 23 Stat. 332, repealed by Act of June 27, 1952, ch. $477, \S 403(\mathrm{a})(2), 66$ Stat. 279-80. others).

145. See id. $\$ 5$ (excepting professional actors, artists, lecturers, and singers, among

146. Holy Trinity Church, 143 U.S. at 459.

147. Id. at 464.

148. See id. at 464-65.

149. Id. at 470-71. 
soning model. According to the model, the text of the statute powerfully supports the government's position, creating a strong presumption for that interpretation. But the apparent meaning of the text becomes less clear when we consider the statute's purpose and legislative history, and test that meaning against background social values. This evidence suggested an alternative reading to the Court, one that emphasized the value of religious freedom, and the Court's faith in this as a "Christian nation." 150 The values of textualism seem little impaired by this reading, and the Court appears admirably sensitive to legislative expectations. The Court's opinion may be more persuasive because it weaves different arguments together to present powerful reasons for rethinking the apparent meaning of the bare text. ${ }^{151}$

\section{Using Practical Reasoning to Evaluate the Supreme CourT's STatutory INTERPRETATION Decisions}

Part I demonstrated several fundamental problems with each of the primary foundationalist theories of statutory interpretation. The Supreme Court, we argued, recognizes these weaknesses at least implicitly, as its unwillingness to rely consistently upon any one of the foundationalist theories suggests. Part II offered a practical reasoning

150. See id. at 464-72. Concededly, the Court's opinion used this backdrop of religious freedom, together with legislative history, to bolster its argument that Congress could not have intended to outlaw what the church had done. Thus this value might be seen as relevant only to the question of statutory intent and purpose. Yet the overall thrust of the opinion, as stated at the outset, is that courts should avoid the literal interpretation of a statute if that would be an "absurd result." See id. at 460 . On this score, the opinion reduces to the following syllogism: (1) courts should avoid absurd interpretations of a statute; (2) in American society, it would be absurd to make criminal what the church had done; (3) therefore, the statute was not violated. By equating what the legislators did not intend with what American society would consider absurd, and by assuming the judicial authority to assess how society would evaluate the statute, the Court in effect said that judicially construed societal values can trump "clear" statutory language. That the legislative intent invoked by the Court is in part actually a judicially constructed sense of societal values is made clear in the last two sentences of the opinion:

It is a case where there was presented a definite evil, in view of which the legislature used general terms with the purpose of reaching all phases of that evil, and thereafter, unexpectedly, it is developed that the general language thus employed is broad enough to reach cases and acts which the whole history and life of the country affirm could not have been intentionally legislated against. It is the duty of the courts, under those circumstances, to say that, however broad the language of the statute may be, the act, although within the letter, is not within the intention of the legislature, and therefore cannot be within the statute.

Id. at 472 .

151. The Holy Trinity Church "purpose" or "spirit" methodology recently came under attack in a specially concurring opinion of Justice Kennedy. See Public Citizen v. United States Dep't of Justice, 109 S. Ct. 2558, 2576 (1989) (Kennedy, J., joined by Rehnquist, C.J. and O'Connor, J., concurring in the judgment). Justice Kennedy complained generally that "the problem with spirits is that they tend to reflect less the views of the world whence they came than the views of those who seek their advice," id., and in particular, he suggested that the Court in Holy Trinily Church simply substituted its "Christian nation" values for those of Congress. As the text demonstrates, however, we find in Holy Trinity Church a much richer combination of arguments supporting its holding. The opinion's unfortunate genuflections toward Christianity should not obscure its central message. 
model as a more subtle description of the Supreme Court's approach to statutory decisions. We argued further that our model is theoretically attractive, because it not only draws upon our reading of the Court's vast array of statutory interpretation decisions, but also seems consistent with modern theories of interpretation and reasoning. ${ }^{152}$ Hermeneutics, for example, suggests that an interpreter cannot escape the pull and influence of various types of arguments, evolutive as well as textual and historical. And pragmatism, we claimed, suggests that interpreters will generally be persuaded by the arguments that best fit the interpreter's web of beliefs and values. Our practical reasoning model mixes inductive and deductive problem-solving techniques, evaluates various arguments according to their "cash value" in the web of beliefs embraced by the interpretive community, and considers the complete textual, historical, and evolutive context of the statutory provision being interpreted.

Our inquiry in this part will have a different focus. Assuming the descriptive accuracy of our funnel-shaped model, we shall use it as a framework from which one can evaluate the Court's practice in statutory cases. There are at least two ways to criticize the Court within this framework. One way is to accept the framework and to analyze the Court's thoroughness and persuasiveness in considering the various factors and in making political choices in the cases. Another way is to question the Court's apparent hierarchy of values that underlie the funnel-shaped model.

Specifically, our practical reasoning model allows us to evaluate the Supreme Court's candor in statutory interpretation. If, as we suggest, the Court ordinarily applies practical reasoning to the interpretation of statutes, does the Court do so carefully and persuasively? Do its opinions adequately reflect that process of practical reasoning? Unhappily, they often do not. Indeed, the Court's opinions show a distressing tendency to overstate the case for the result that a majority of the Justices prefer, and to suppress the legitimate arguments cutting in a different direction. This is distressing, because the full advantages of a practical reasoning approach cannot be realized without a candid "to and fro" play among the various interpretive considerations, as Gadamer's account of the hermeneutical attitude suggests. We explore this problem in the first section of this part.

Our model also serves as a framework by which to evaluate the Court's consideration of various interpretive factors. In our view, the Court often gives too much weight to historical factors and rigid textual readings. Even in instances where evolutive considerations were probably decisive to the outcome, the Court's opinions frequently submerge

152. We have previously addressed many of the policy and constitutional arguments that might be raised against our position. See, e.g., Eskridge, supra note 3; Farber \& Frickey, Legislative Intent, supra note 3. 
these factors and sound more "archaeological"153 than was the decisionmaking process that likely produced the result. In other instances, the Court's neglect of evolutive factors seems to make a difference in the result as well as the opinion. We explore this phenomenon in the second section of this part.

These two observations-the Court's tendency to overstate arguments supporting its results and to understate the importance of evolutive factors-are related to one another, and related to what must be the primary reason for the continuing appeal of foundationalist theories of statutory interpretation: The Court remains insecure in the legitimacy of its statutory interpretations. To justify such interstitial lawmaking, the Court feels it must establish a compelling case for the interpretation based upon "objective" evidence, preferably tied to legislative (majoritarian) expectations. This observation is neither new nor striking, and we do not linger on it.

What we do develop is the thesis that this "counter-majoritarian anxiety" in statutory interpretation, so obviously related to similar insecurities in constitutional decisionmaking, might be relieved by examining similar issues in other disciplines, especially philosophy and historiography. Like law, these disciplines have traditionally sought certitude through demonstrations that conclusions rest upon "objective" foundations and are thus not vulnerable to the accusations of "subjectivism" and "relativism." Inspired by both the hermeneutical and pragmatic traditions, however, modern philosophers and historians have attacked this traditional opposition and have sought, in Richard Bernstein's words, to move "beyond objectivism and relativism"154 toward a dialogic understanding of human knowledge. Statutory interpretation ought to make a similar movement, acknowledging that to admit that legal interpretations often cannot be established according to clear objective criteria is not to bestow upon the judge unconstrained freedom to reach any interpretation she desires. If performed candidly and with empathetic appreciation for the point of view of others (the classic assumptions of hermeneutics), the to and fro movement among the considerations suggested by our practical reasoning model is a more legitimate approach to statutory interpretation than the supposedly "objective" foundationalist approaches.

\section{A. Internal Critique of the Court's Practical Reasoning}

Parts I and II of this article suggest that the Supreme Court has not embraced, and ought not embrace, any one foundationalist method of statutory interpretation. We argued that the best way to understand the corpus of Supreme Court opinions is to view them as applications of our practical reasoning approach, as Griffin and Holy Trinity Church

153. See Aleinikoff, supra note 85 .

154. R. BeRnStein, Beyond OBJectivism, supra note 8. 
illustrate. Although our model captures what the Supreme Court actually does in statutory interpretation cases, we readily concede that many of the Court's written decisions seem to adopt one of the foundationalist approaches. This is only superficially disturbing to our thesis, because decisions typically cited as examples of literalism (Griffin) or purposivism (Weber) are in fact much more complicated in their reasoning. Our thesis is bolstered by the observation that, even if these decisions were read to endorse foundationalist approaches, they adopt different foundationalist approaches. For every case that might be cited for a purposivist approach (Weber), there is a counter-case that might be cited for a textualist approach (Griffin). When these cases are read carefully, and especially when they are read together with similar cases over time, one realizes that they do not stand for any foundationalist approach, but instead are more naturally explained by our model of practical reasoning. One critical suggestion we derive from Parts I and II is that the Court should abandon its foundationalist rhetoric, because it only impedes an understanding of how the Court actually engages in statutory interpretation.

An equally distressing phenomenon is that even when the Court explicitly considers the various factors of practical reasoning, it often treats interpretive considerations mechanically and suppresses opposing evidence. The Court's written opinions in statutory cases are often wooden or one-sided: The Court unrealistically asserts that all of the interpretive factors support the Court's interpretation or are at least neutral; very often the Court simply ignores those considerations that point in a different direction. This style of suppressing disagreement defeats the whole purpose of practical reasoning, that of understanding opposing evidence and trying to derive a practical solution in the specific case at hand. The hermeneutical play between interpreter and text does not occur when the interpreter fails to give herself over to the to and fro movement, in which all useful and relevant evidence is considered, and disagreement is embraced rather than suppressed. Of course, disagreement is not entirely suppressed by a one-sided opinion, for it typically provokes an equally one-sided dissent. We think it better, however, for each Justice to recognize the complexities of his or her position, and for the Court as a whole to write opinions that better reflect the complex decisionmaking process.

Weber is a classic example of this problem. Justice Brennan's opinion for the Court purports to demonstrate that original congressional expectations justify an interpretation permitting affirmative action under Title VII. But the words Congress chose for Title VII do not readily suggest that Congress in 1964 approved of affirmative action or even thought much about it, and Justice Brennan's opinion refuses even to attempt to identify any ambiguity in the statutory text that cuts against his interpretation. Nor does the opinion concede that much of the legislative history, meticulously collected in Justice Rehnquist's dis- 
sent, speaks against Justice Brennan's interpretation as well. Instead, the opinion deflects attention from those factors by blandly invoking the maxim that an interpretation should be accepted if it is within the "spirit," even if not the letter, of the statute. ${ }^{155}$ The opinion appeals to one purpose of the statute-ensuring more jobs for blacks-without recognizing that another purpose of the statute-encouraging colorblind decisions-cuts against the Court's interpretation. Overall, Justice Brennan's opinion is supported more by assertion than by a careful review of the many pieces of evidence.

Justice Brennan's opinion in Weber does not adequately articulate the practical reasoning that ultimately does support his conclusion, because it treats the various interpretive factors selectively and somewhat capriciously, and fails to acknowledge the force of current values and policies that must have influenced the result. Neither is Justice Rehnquist's dissent a paradigm for a decision grounded in practical reason, however, for his attack on the majority itself rests upon an overstated view of the evidence ${ }^{156}$ and on a selective analysis of the important interpretive factors. It is the concurring opinion by Justice Blackmun that best suggests at least some of the practical considerations that probably swung a majority of the Justices to the Weber result. Justice Blackmun refreshingly admitted that the historical evidence canvassed in the dissenting opinion had great force, and declined to find much determinate meaning in either the text or the purpose of the statute. Rather, Justice Blackmun considered unforeseen developments since 1964 and concluded that it would be practically unfair to employers and unions-and the beneficiaries of Title VII-not to allow voluntary affirmative action in some circumstances. ${ }^{157}$

Weber is not unusual. Our complaints that both majority and dissenting opinions seem to (but only seem to) submerge the various inter-

155. Justice Brennan noted that Weber's argument rested upon "a literal interpretation" of $\$ \S 703(a)$ and (d) and did acknowledge that the argument was "not without force." But he found the argument "misplaced," because of the "ffamiliar rule, that a thing may be within the letter of the statute and yet not within the statute, because not within its spirit, nor the intention of its makers.'" 443 U.S. at 201 (quoting Holy Trinity Church). Note that the opinion nowhere suggests any ambiguity in $\$ \S 703$ (a) and (d) or why, if there is no ambiguity, the spirit of the statute should have controlled over its plain meaning. Yet, later in the opinion, Justice Brennan inconsistently invoked the plain meaning approach to trump an argument based on statutory purpose. Section 703(j) provides that nothing in the statute "shall be interpreted to require any employer" to engage in affirmative action. 42 U.S.C. $\$ 2000 \mathrm{e}-2(\mathrm{j})$ (1982) (emphasis added). The seemingly color-blind spirit of this provision was irrelevant, Justice Brennan claimed, because

[h] ad Congress meant to prohibit all race-conscious affirmative action, . . . it easily could have ... provid[ed] that Title VII would not require or permit racially preferential integration efforts .... The section does not state that "nothing in Title VII shall be interpreted to permit" voluntary affirmative efforts to correct racial imbalances. The natural inference is that Congress chose not to forbid all voluntary race-conscious affirmative action.

443 U.S. at $205-06$ (emphasis in original).

156. See R. DworkIN, supra note 15, at 324-26.

157. 443 U.S. at 209-16 (Blackmun, J., concurring). 
pretive factors in favor of one overriding consideration, and fail to acknowledge the complexity of the evidence, are equally applicable to other statutory interpretation opinions, ${ }^{158}$ including Bob Jones. ${ }^{159}$ In many more cases, the Court explicitly examines the many considerations that our practical reasoning model suggests, but examines the evidence in questionable ways. Recall that our descriptive model finds that the Court will make political choices. If that is true, it may make poor political choices and render ill-informed statutory judgments. An example of this is the Court's recent opinion in McNally $v$. United States. ${ }^{160}$

McNally interpreted the federal mail fraud statute, which criminalizes "any scheme or artifice to defraud, or for obtaining money or property by means of false or fraudulent pretenses, representations, or promises" using the federal mails. ${ }^{161}$ The Court held that the "fraud" prohibited in the statute is limited to schemes to deprive others of money and other property rights and does not include schemes to deprive others of "intangible rights," such as the right of the citizenry to fiduciary honesty on the part of public officials. The Court's opinion tracks the considerations outlined in our model of practical reasoning. As first enacted in 1872, the mail fraud statute was aimed at "thieves, forgers, and rapscallions ... deceiving and fleecing the innocent people in the country." 162 From that the Court concluded that "the original impetus behind the mail fraud statute was to protect the people from schemes to deprive them of their money or property." 163 According to the Court, the statutory text confirms this interpretation, because the key term "to defraud" has traditionally (in 1872 as well as in this century) been limited to " "wronging one in his property rights by dishonest methods or schemes." "164 Further confirmation of this interpretation was the judicially ascribed statutory " 'purpose of protecting the public against all such intentional efforts to despoil" " peo-

158. See, e.g., Wards Cove Packing Co. v. Atonio, 109 S. Ct. 2115 (1989); Chan v. Korean Airlines, Ltd., 109 S. Ct. 1676 (1989); Regents of the Univ. of Cal. v. Public Employment Relations Bd., 108 S. Ct. 1404 (1988); United States v. Johnson, 481 U.S. 681 (1987); Sorenson v. Secretary of the Treasury, 475 U.S. 851 (1986); Bankamerica Corp. v. United States, 462 U.S. 122 (1983).

159. Chief Justice Burger's opinion for the Court all but ignored the plain meaning of the statutory language and the history of the statute and seized upon an oversimplified purpose analysis. 461 U.S. at 577-605. Justice Rehnquist's dissent, which is analytically quite powerful, is also somewhat one-sided, as it slights the dynamic purpose and constitutional policy ramifications of the statute. Id. at 612-23. The concurring opinion of Justice Powell is candid about the strength of arguments on both sides and is an eloquent testament to the persuasiveness of evolutive and practical factors. Id. at 606-12.

160. McNally v. United States, 483 U.S. 350 (1987).

161. 18 U.S.C. $\S 1341$ (1982).

162. Cong. Globe, 41 st Cong., 3d Sess. 35 (1870) (remarks of Rep. Farnsworth), quoted in MiNally, 483 U.S. at 356.

163. McNally, 483 U.S. at 356.

164. Id. at 358 (quoting Hammerschmidt v. United States, 265 U.S. 182, 188 (1924)). 
ple of their money and property. ${ }^{165}$ The Court also traced the evolution of the statute through Supreme Court interpretations and congressional amendments to support its narrow view. Finally, the clinching argument was the rule of lenity, a canon of interpretation concerned with avoiding unfair surprise and other consequences that can result from reading a federal criminal statute too broadly. ${ }^{166}$

McNally would appear to be a wonderfully practical opinion, persuasively weaving together the various factors like threads in a cable-until one looks at the evidence. The Court built its case, according to which every one of the factors supports the Court's interpretation, by ignoring or suppressing quite substantial evidence going the other way. Fortunately, Justice Stevens, in dissent, assembled the evidence and used the same practical reasoning factors to disassemble the Court's analysis, factor by factor. ${ }^{167} \mathrm{He}$ noted, for example, that the text of the statute seems at war with the Court's interpretation. By interpreting "to defraud" to include only deceptions involving money or property, the Court seems to render the prohibition substantially duplicative of the next clause, which criminalizes any scheme "for obtaining money or property by means of false or fraudulent pretenses, representations, or promises." 168 While not an unyielding rule, the Court will try to interpret a statute to avoid redundancy of separate statutory language. ${ }^{169}$ This suggestive argument finds support in the meaning of the term "to defraud." Contrary to the Court's opinion, the longstanding legal definition of "defraud" includes concealment of important information in a fiduciary setting, and interpretations of other federal statutes have not limited its scope to property fraud. ${ }^{170}$ Here common sense coincides with legal sense. When a public official takes a bribe, we the people are "defrauded" just as though she were a realtor lying to us about the drainage on a piece of property. We are deprived of the fiduciary's honest service to us.

Nor is there a "smoking gun" in the historical evidence suggesting that the 1872 Congress either specifically intended a narrower definition of "to defraud," or even gave any thought to the precise issue

165. Id. at 357 (quoting Durland v. United States, 161 U.S. 306, 314 (1896)).

166. Id. at 360 :

Rather than construe the statute in a manner that leaves its outer boundaries ambiguous and involves the Federal Government in setting standards of disclosure and good government for local and state officials, we read \$ 1341 as limited in scope to the protection of property rights. If Congress desires to go further, it must speak more clearly than it has.

167. Id. at 362-77 (Stevens, J., dissenting).

168. 18 U.S.C. $\S 1341$ (1982).

169. See, e.g., Mackey v. Lanier Collections Agency \& Serv., 108 S. Ct. 2182, 2188-89 (1988). Of course, the next clause is duplicative under either interpretation of "defraud." The overlap is more striking under the Court's interpretation.

170. McNally, 483 U.S. at $371-73$ (Stevens, J., dissenting) (following United States v. Holzer, 816 F.2d 304, 307-08 (7th Cir. 1987) (Posner, J.)). 
before the Court. ${ }^{171}$ An imaginative reconstruction of what the 1872 Congress might have meant is no more helpful to the Court's interpretation, because nineteenth century use of the term "to defraud" reached actions seeking "to withhold from another that which is justly due to him, or to deprive him of a right by deception or artifice." 172 Moreover, one major statutory purpose conflicts with the Court's interpretation. The Court has long recognized that a primary purpose of the statute is "to protect the integrity of the United States mails by not allowing them to be used 'as instruments of crime." "173 To allow the mails to be used to perpetrate fiduciary crimes, but not property crimes, is to read into the statute a fiction unsupported by what might be characterized as the main legislative purpose.

Some, but not all, of the evolutive factors cast doubt on the Court's interpretation. The statute's development has been a steady expansion of its ambit to reach new kinds of fraud, and Congress has neither restricted these expansions, nor even expressed any reservations about them. ${ }^{174}$ Even the rule of lenity does not unequivocally support the Court's result. While the rule does support the Court's reluctance to give the mail fraud statute broad application, its force is undermined by the longstanding interpretation that all lower courts have given, applying it to fiduciary frauds. Indeed, the obvious illegality of the conduct to which the statute has been applied undermines the Court's interpretation. A public official directing government contracts to a buddy in return for extensive kickbacks (the facts of McNally) knows that the conduct is fraudulent and cannot claim "surprise" that a statute aimed at fraud might be applied to such conduct.

When a wide variety of federal judges, faced with concrete examples of illicit behavior by state officials, have uniformly filled an enforcement vacuum by using a general federal criminal statute amenable to such an interpretation, it strikes us as impractical for the Supreme Court to cut off this statutory evolution root and branch. McNally seems wrong not because the Court failed to invoke practical reasoning, but because the Court applied the factors so mechanically and abstractly, without giving a fair and balanced assessment of the evidence. The Court's opinion violates the hermeneutical spirit, which impels the interpreter to embrace evidence running against her tentative views and to try to learn from it, thereby reaching a more mature judgment. Similarly, the opinion breaches the central teaching of pragmatism, which emphasizes "concreteness" and "facts," with an eye to "the open air and possibilities of nature, as against dogma, artificiality, and the pretense of finality

171. Id. at 373-74.

172. I Bouvier's Law Dictionary 530 (1897). This and a number of similar usages are quoted in Justice Stevens' dissent. McNally, 483 U.S. at 370-71.

173. 483 U.S. at 365-66. (Stevens, J., dissenting) (quoting United States v. Brewer, 528 F.2d 492, 498 (4th Cir. 1975), and citing a number of similar cases).

174. Id. at 374 . 
in truth." 175 Put more bluntly, the Court's opinion in McNally hides the ball. It seems implausible that the analysis in the Court's opinion persuaded even the seven Justices who joined it, and the Court missed an excellent opportunity to ventilate the mail fraud statute with some candid discussion.

Faced with the unpersuasiveness of the Court's written opinion, the hermeneutic interpreter would seek to retrieve the concrete facts or ideas that must have moved the Justices in McNally. In our view, $M c$ Nally's core concern was to prevent limitless elasticity in the coverage of a broadly phrased federal criminal statute. The mail fraud statute has evolved through ever-expansive judicial interpretation, to reach both new and old forms of fraud. This is on the whole commendable. The further the statute has expanded, however, the more problematic that expansion has become, for the statute presses against the rule of lenity, seems to federalize areas traditionally left to the states, and risks selective, partisan enforcement of the statute (since a United States Attorney appointed by the President is prosecuting a local or state political figure). The stakes for these concerns are indeed quite high, since mail fraud statute violations can be predicate offenses justifying the potentially harsh sanctions of the RICO statute. ${ }^{176}$ Given these concerns, and the step-by-step expansion of the statute in the lower courts, the lesson to learn from McNally would be that we have to find a limiting principle for this open-ended statute, which the judiciary has already expanded so dramatically.

At first glance, one plausible limiting principle would seem to be the one that the Court chose. Focusing on fraud involving property has several advantages. It fits nicely with the original core concerns of the 1872 version of the statute, does not clearly contravene the Court's earlier interpretations of the statute, and carves out of the statute many of the most sensitive cases, such as those threatening state officials and party bosses with prosecution for patronage by a United States Attorney who belongs to a different political party. As the Court suggested, it would be perfectly appropriate for Congress to expand the statute to include these sensitive cases expressly, and indeed Congress effectively did so a year later. ${ }^{177}$ Having Congress rather than the Court broaden the statute would open public debate of the issues and lend greater legitimacy to the federal intrusion into state politics.

These are the considerations we think actually motivated the Justices in McNally. But we do not find even this articulated defense of the Court's position wholly persuasive, because the open-ended statutory

175. W. JAMEs, supra note 6 , at 51 .

176. 18 U.S.C. $\S 1961$ (1) (1982); see Sedima, S.P.R.L. v. Imrex Co., 473 U.S. 479, 500 (1985) (Marshall, J., dissenting).

177. See Pub. L. No. 100-690, $\$ 7603,102$ Stat. 4508 (1988) ("the term 'scheme or artifice to defraud' includes a scheme or artifice to deprive another of the intangible right of honest services"). 
language invites judicial elaboration, and because there seems to be little contemporary doubt that referral and kickback scams by state offcials are squalid and "fraudulent" in any meaningful sense of the term. Moreover, the Court could have trimmed the ambit of the mail fraud statute in a number of other ways. For example, in United States v. Margiotta, ${ }^{178}$ an excellent dissenting opinion by Judge Ralph Winter raised cogent objections to the Second Circuit's extension of officials' fiduciary duty to include political bosses who hold no formal public office. Judge Winter argued against this expansive reading of public fiduciary duty, even while accepting that the statute covered intangible rights. And since one of the defendants in McNally was a party leader with no formal government post, the Court in McNally could have limited the mail fraud statute in just this way, by exempting nonpublic officials who allegedly violate the public trust. Had the Court crafted this narrower limitation on the mail fraud statute, it would have stimulated public debate that might have led Congress to amend the statute. But it would not have removed the statute from a natural area for federal regulation. ${ }^{179}$

The practical reasoning methodology we propose is more than a multifactored, anti-foundationalist approach. Its distinctive features are its focus on the concrete and avoidance of opinions that sweep more broadly than necessary (unlike McNally), its willingness to acknowledge indeterminacy and conflicting values rather than indulge in makeweight arguments (unlike Weber), and its effort to engage in a dialectic of interpretation (unlike either decision). This last point is perhaps the most critical. Too often the Court's statutory interpretations ignore opposing arguments or treat them in a dismissive, mechanical fashion, typically in footnotes, and too rarely do they engage in an open dialogue that notes the virtues of various positions and explains why one of them is preferable. Such a dialogue would improve the quality of the Court's opinions and provide more solid guidance for lower courts, which must interpret the Court's opinions, and for Congress, which might want to amend the statute in response to the Court's concerns. It also might alter the results in some of the Court's most unconvincing opinions, such as McNally.

\section{B. External Critique of the Court's Reluctance to Admit the Importance of Evolutive Factors}

An important feature of our practical reasoning model is its focus on evolutive factors, in addition to the more traditional textual and his-

178. 688 F.2d 108, 121-23 (2d Cir. 1982) (Winter, J., dissenting), cert. denied, 461 U.S. 913 (1983).

179. Another way to limit the mail fraud statute would focus on the mail aspect of it, as by requiring that the use of the mails (the federal trigger) be critical to the fraudulent scheme. The Court has not chosen this path, however. See Schmuck v. United States, 109 S. Ct. 1443 (1989). 
torical factors. If interpretation is a fusion of horizons, our current vantage point will always exercise some influence on the common ground we reach with an historical text. Older statutes, especially when they are generally phrased, may obviously require an imaginative process of fusion with our more distant horizon. In these cases, the text and legislative history will usually not be terribly helpful, and the Court will find evolutive considerations the only way to mediate the temporal distance. This is why evolutive factors were so important in Bob Jones, which interpreted a very old statute. But even recent statutes may involve a difficult process of interpretation under our model. Weber, for example, interpreted a more recent statute, but one whose assumptions were undone in a very short time; although the statute in that case was only fifteen years old, the fusion of horizons that Weber demanded was comparatively difficult. What is striking, and troubling, is that in all three cases the Court was very reluctant to acknowledge the force of evolutive considerations. ${ }^{180}$ And even when the Court does concede the importance of evolutive factors, the concession is often made reluctantly, even grudgingly. Consider the following case.

In Bryan v. Itasca County, ${ }^{181}$ Minnesota sought to tax the personal property of a Native American who lived on a federal Indian reservation. In general, longstanding precedent provides that, absent congressional consent, state laws do not apply to reservation Indians within the reservation. ${ }^{182}$ The issue in Bryan was whether federal Pub-

180. In none of the three cases did the Court clearly acknowledge the importance of evolutive factors, though concurring opinions in V'eber (by Justice Blackmun) and Bob Jones (by Justice Powell) explicitly invoked evolutive factors as decisive for them. For other recent cases where concurring opinions flesh out evolutive considerations suppressed by the Court's opinions, see Price Waterhouse v. Hopkins, 109 S. Ct. 1775, 1796 (1989) (O'Connor, J., concurring in the judgment); Mesa v. California, 109 S. Ct. 959, 970 (1989) (Brenman, J., concurring); Sheridan v. United States, 108 S. Ct. 2449, 2456 (1988) (Kennedy, J., concurring in the judgment); $\mathrm{K}$ Mart Corp. v. Cartier, Inc., $108 \mathrm{~S}$. Ct. 1811 , 1819 (1988) (Brennan, J., concurring in part); United States v. Fausto, 108 S. Ct. 668, 677 (1988) (Blackmun, J., concurring); Welch v. Texas Dep't of Highways \& Pub. Transp., 483 U.S. 468, 495 (1987) (Scalia, J., concurring in part and concurring in the judgment); Rose v. Rose, 481 U.S. 619, 636 (1987) (O'Connor, J., concurring in part and concurring in the judgment); NLRB v. International Bd. of Elec. Workers, Local 340, 481 U.S. 573, 596 (1987) (Scalia, J., concurring in the judgment); Lukhard v. Reed, 481 U.S. 368, 383 (1987) (Blackmun, J., concurring in the judgment); Johnson v. Transportation Agency, 480 U.S. 616, 642 (1987) (Stevens, J., concurring); California Fed. Sav. \& Loan Ass'n v. Guerra, 479 U.S. 272, 292 (1987) (Stevens, J., concurring in part and concurring in the judgment); Pembaur v. City of Cincinnati, 475 U.S. 469,487 (1986) (Stevens, $J$., concurring in part and concurring in the judgment); Pattern Makers' League $v$. NLRB, 473 U.S. 95, 116 (1986) (White, J., concurring).

For recent cases where the Court ignored evolutive factors even while reaching results consistent with (and surely influenced by) such arguments, see, e.g., Blanchard v. Bergeron, 109 S. Ct. 939 (1989); Pittston Coal Group v. Sebben, 109 S. Ct. 414 (1988); Boyle v. United Technologies Corp., 108 S. Ct. 2510 (1988); Forrester v. White, 484 U.S. 219 (1988); Puerto Rico v. Branstad, 483 U.S. 219 (1987); Shaare Tefila Congregation v. Cobb, 481 U.S. 615 (1987); St. Francis College v. Al-Khazraji, 481 U.S. 604 (1987); Smith v. Murray, 477 U.S. 527 (1986); Japan Whaling Ass'n v. American Cetacean Soc'y, 478 U.S. 221 (1986).

181. 426 U.S. 373 (1976).

182. See, e.g., McClanahan v. Arizona State Tax Comm'n, 411 U.S. 164 (1973); Worcester v. Georgia, 31 U.S. (6 Pet.) 515 (1832). 
lic Law $280^{183}$ authorized the state tax. Section 4 (a) of this statute provided that several states, including Minnesota,

shall have jurisdiction over civil causes of action between Indians or to which Indians are parties which arise in [specified areas of Indian country] ... to the same extent that such State or Territory has jurisdiction over other civil causes of action, and those civil laws of such State... that are of general application to private persons or private property shall have the same force and effect within such Indian country as they have elsewhere within the State ... ${ }^{184}$

The state seized upon the second clause of section 4(a) to support its asserted power to tax. In addition, it noted that section 4(b) of the statute expressly exempted from state taxation certain sorts of Native American property, ${ }^{185}$ but not the kind at issue in Bryan, thereby suggesting by negative implication that the state tax was proper.

The unanimous Court disagreed with this strong textualist argument, essentially holding that other interpretive factors outweighed the apparent meaning of the statutory text. Public Law 280, the Court concluded, had been adopted almost entirely because, under the statute's other provisions, certain states received criminal jurisdiction over $\mathrm{Na}$ tive American territory. Congress added the civil jurisdictional provision at issue in Bryan largely as an afterthought. The legislative history failed to reflect any consideration of whether it was intended generally to extend state legislative authority-as opposed to state civil court jurisdiction-into Native American territory. The Court invoked the longstanding canon of interpretation that federal statutes will not be interpreted to diminish tribal sovereignty absent a clear statement to that effect in statutory language or legislative history. ${ }^{186}$ This canon-a judicial policy judgment intended to preserve tribal sovereignty unless the contrary outcome is congressionally compelled-trumped the general language of the civil jurisdictional provision, since the state had not shown a specific congressional intention to extend its legislative power.

Only at the end of its opinion did the Court more directly acknowl-

183. Pub. L. No. 280,67 Stat. 589 (1953) (codified in relevant part at 28 U.S.C. $\$ 1360$ (1982)).

184. 28 U.S.C. $\$ 1360$ (a) (1982).

185.

Nothing in this section shall authorize the alienation, encumbrance, or taxation of any real or personal property, including water rights, belonging to any Indian or any Indian tribe, band, or community that is held in trust by the United States or is subject to a restriction against alienation imposed by the United States; or shall authorize regulation of the use of such property in a manner inconsistent with any Federal treaty, agreement, or statute or with any regulation made pursuant thereto; or shall confer jurisdiction upon the State to adjudicate, in probate proceedings or otherwise, the ownership or right to possession of such property or any interest therein.

28 U.S.C. § 1360 (b) (1982).

186. On such canons of construction, see generally Charles F. Wilkinson \& John $\mathrm{M}$. Volkman, Judicial Review of Indian Trealy Abrogation: "As Long as Waler Flows, or Grass Grows upon the Earth"-How Long a Time Is That?, 63 Calif. L. Rev. 601 (1975). 
edge the evolutive sources of its interpretation. It noted that Congress had adopted Public Law 280 during an era in which the federal policy was to force assimilation of Native Americans, but that Congress had abandoned that policy in short order. An extension of state legislative power over Native American territory, the Court reasoned, might be devastating to the tribes. ${ }^{187}$ For all these reasons, the Court interpreted the second clause of section $4(\mathrm{a})$ as simply authorizing state courts to apply their own rules of decision, and not those found in tribal law, to the civil cases over which they were granted jurisdiction.

Bryan is a useful illustration of the way in which evolutive considerations are often the decisive ones in statutory interpretation. On the face of the statute, Minnesota probably had the better argument. ${ }^{188}$ There was apparently nothing very specific in the legislative history, but if the enacting Congress had been asked about the Bryan issue while it was considering Public Law 280, one would guess that the answer would have supported Minnesota as well. Indeed, it would be difficult to find a Congress in this century that seemed more clearly animated by the desire to destroy tribal sovereignty. For in addition to enacting Public Law 280, the 1953 Congress adopted a concurrent resolution that created the federal policy of terminating the unique federal legal status-and thus the sovereignty-of Native American tribes. ${ }^{189} \mathrm{~A}$ legal-process purpose inquiry might also support Minnesota, since the purpose of Public Law 280 was to extend state authority over certain

187. The Court quoted with approval the view of the Ninth Circuit that courts " are not obliged in ambiguous instances to strain to implement [an assimilationist] policy Congress has now rejected, particularly where to do so will interfere with the present congressional approach to what is, after all, an ongoing relationship.' " Bryan, 426 U.S. at 388 n.14 (quoting Santa Rosa Band of Indians v. Kings County, 532 F.2d 655, 663 (9th Cir. 1975)) (brackets in original).

188. If read in isolation, the second clause in $\$ 4$ (a) of Public Law 280, which deals with state laws of general application, seems to support Minnesota's argument that its taxing statutes reached Indian country. When read within the context and structure of the rest of \$ 4(a), however, that interpretation loses some of its force. This is so because the preceding clause of $\$ 4$ (a) simply grants state courts civil jurisdiction over cases arising in Indian country, and when both clauses are read together the second one can be plausibly interpreted the way the Court did in Bryan - as providing simply that state law rules of decision, not tribal law rules of decision, govern the cases over which state court jurisdiction is granted by the first clause. Indeed, the two clauses of $\S 4(a)$ are linked by the conjunction "and" into one sentence, fortifying the Court's interpretation that the seemingly broad language of the second clause must be seen through the narrowing lens of the first clause. Cutting against this approach, however, is the language of $\S 4(\mathrm{~b})$, which is quoted in note 185 supra. Section 4 (b) carves out some exceptions to the grant of state power provided by $\$ 4(a)$, and several of these exceptions seem to contemplate that state legislative power controls in Indian country unless otherwise excepted. This argument based on the negative implications of $\S 4(b)$ is another example of the expressio unius maxim - that the expression of some exceptions implies that the legislature intended those to be the only exceptions. This maxim is ordinarily a weak reed upon which to base an interpretation, because it is based on the faulty assumption of legislative omniscience. See W. EsKRIDGE \& P. FRICKEY, supra note 1, at 641-42. It is often rejected by courts, as Holy Trinity Church exemplifies. Nonetheless, on the face of $\S \S 4(a)$ and (b), Minnesota probably had the stronger argument in Bryan.

189. H.R. Con. Res. 108, 67 Stat. B132 (1953). 
tribal Indians. ${ }^{190}$ These legislative intentions and purposes, however, became obsolete within about five years. By the time Bryan made its way to the Supreme Court, the firmly established federal policy was to promote tribal sovereignty. 191

The Court is rarely as forthright in considering evolutive factors as it was in Bryan. But while we believe the case was correctly decided, even the Bryan opinion is hardly as candid as it might have been. For example, Bryan essentially ignores the statutory language, which does cut against its interpretation. Rather than admit that the language must be weighed otherwise, the Court simply announced that its apparent thrust "is foreclosed by the legislative history ... and the application of canons of construction." 192 Yet the legislative history itself is murky, and the Court did not openly grapple with the reasons for ignoring apparent textual meaning. While the Court recognized that evolutive factors weighed heavily against the assertion of state taxing authority, it buried most of this discussion in a footnote. ${ }^{193}$ The opinion ends with the somewhat doubtful assertion that because Congress knows that the Court will require a clear statement before it interprets a statute to diminish tribal sovereignty, ${ }^{194}$ Congress's failure to write the statute in a crystal-clear manner suggests that it must have intended the result reached in Bryan. Astonishingly, the opinion places the responsibility for the result upon a long-adjourned Congress that surely gave no thought at all to the issue, rather than upon the Court itself, which created the controlling interpretive presumption and reached a result very much at odds with whatever original intentions could probably be reconstructed.

Typically, the failure of the Court to acknowledge the force of evolutive factors is simply a failure of candor, since it is apparent that the Court or at least some of the Justices have considered those factors seriously. ${ }^{195}$ In other cases, however, this failure may affect the result. Consider our last example, United States v. Kozminski. ${ }^{196}$ Section 1584 of the Criminal Code makes it a federal crime knowingly and willfully to

190. Like most purpose inquiries, however, this one is quite indeterminate. Minnesota would point to a broad purpose of assimilating the affected bands of tribal Indians; the tribes would respond that the narrow purpose of Public Law 280 was to provide criminal enforcement and a forum for civil adjudication in several states where Congress deemed the tribal justice system inadequate. Yet even this narrower purpose might suggest that Minnesota should have the power to tax Indian property, thereby raising revenue to offset the state's expenses incurred in providing the criminal enforcement and judicial forums required of it by Public Law 280.

191. The policy of coerced termination lost force by 1958. Both candidates in the 1960 presidential campaign supported abandoning the termination policy. Since 1961 tribal selfdetermination, not termination, has been the dominant federal policy. See generally HaNDBOoK OF FEDERAL Indian Law 180-206 (R. Strickland 2d ed. 1982).

192. Bryan, 426 U.S. at 379.

193. Id. at 388 n.14.

194. Id. at 392-93.

195. See note 180 supra.

196. 108 S. Ct. 2751 (1988). 
hold another person "to involuntary servitude."197 The issue in the case was whether the statute prohibits servitude induced by psychological pressure, as well as by physical or legal threats. A majority of the Court held that it does not.

The Court's opinion closely tracks our practical reasoning model, emphasizing the historical factors. To begin with, the Court found the textual prohibition of "involuntary servitude" to be based upon, and certainly parallel to, the similar prohibition in the thirteenth amendment. When section 1584 was added to the Criminal Code in 1948, all of the Court's thirteenth amendment opinions "involved compulsion of services through the use or threatened use of physical or legal coercion."198 Moreover, the Court found the specific legislative history of the statute aimed most directly at traditional means of enslavement, namely physical or legal coercion, and concluded that the broader interpretation sought by the Government would take the statute too far beyond its original purposes. 199

The Court also gave explicit consideration to evolutive factors, but found them insufficient to justify expanding the original intent and purpose of section 1584. The Government and four Justices who concurred only in the judgment urged that the Court develop standards by which psychological coercion could be a basis for conviction under the statute.200 The Court declined that opportunity, on rule of lenity grounds: No sufficiently "objective" test could be devised that would give proper notice to defendants as to what conduct might be illegal, and that would place needed restraints on prosecutorial and jury discretion. ${ }^{201}$

We find the Court's opinion in Kozminski to be a good example of our practical reasoning model in operation, and on the whole we believe the Court was candid and reasonable in its consideration of all the evidence. The Court's analysis does not sufficiently consider current fairness, however. Nor does it adequately consider the fact that the text of the statute is open-ended. While an interpretation of the statute permitting conviction for psychologically inducing a victim into virtual servitude probably would, as the Court indicates, expand the statute beyond its drafters' expectations, by criminalizing "involuntary servitude" without any elaboration or definition, Congress was delegating to the Court the articulation of standards. ${ }^{202}$ The Court's definition, which excludes any kind of "psychological" coercion from the term "in-

197. 18 U.S.C. $\$ 1584$ (1982) authorizes criminal punishment of "[w] and willfully holds to involuntary servitude or sells into any condition of involuntary servitude, any other person for any term."

198. 108 S. Ct. at 2761 (citing cases).

199. Id. at 2761-63.

200. Id. at 2763 (describing Government's position); id. at 2765-69 (Brennan, J., concurring in the judgment); id. at 2771-74 (Stevens, J., concurring in the judgment).

201. Id. at 2764-65.

202. Id. at 2772-73 (Stevens, J., concurring in the judgment). 
voluntary," seems almost a contradiction in terms. Surely the open texture of the statute allows, indeed invites, the Court to find criminal liability in some cases where the coercion is psychological.

The Court's response is that any test of psychological coercion would be too vague. Given the rule of lenity concerns, this might seem persuasive, as an abstract matter. But one weakness of the Court's per se approach is that it requires the case to be considered as an abstract matter. The facts of the case, by contrast, are ideal for a limited expansion of the statute's scope. The victims in the case were two men over 60 years old but with mental ages of eight to ten years. The defendants allegedly brought the victims to their farm and used various psychological measures-including denial of pay, subjection to substandard living conditions, isolation from others, lies, third party pressure, and verbal abuse-to induce the victims to stay. The Government also presented evidence of physical or legal threats, but the core of its case was the psychological coercion. While psychological pressure goes well beyond the core abuses against which section 1584 was originally directed, our current understanding of its power makes it anomalous to say that psychological coercion is less abusive than physical or legal coercion that admittedly violates the statute. ${ }^{203}$

Kozminski, we repeat, is a thoughtful opinion that reflects the Court at its best. Yet the case demonstrates the Court's typical reluctance to follow evolutive considerations when they cut against historical evidence, even in a classic instance where historical concerns ought to yield to evolutive ones. The text of the statute interpreted in Kozminski invites judicial development of the statute on a case-by-case basis, and the historical evidence is highly general, with no smoking gun in the legislative history suggesting that Congress thought about the precise issue and reached any kind of binding consensus. The evolutive concerns are very strong if, as we suspect, the coercive force of psychological pressure is better understood today than when the statute was enacted. In this respect, Kozminski seems similar to Bryan, where the Court reached the evolutive result, and somewhat stronger than Weber, where the Court reached the evolutive result in the teeth of strongly contrary historical evidence.

Practical reason suggests that the Court ought to be candid about the influence of evolutive considerations, unlike the waffling opinion in Bryan, and ought not to trump up makeweight historical or textual arguments when the primary grounds for the opinion are evolutive, as the Court did in Weber and Bob Jones. Furthermore, practical reason suggests that where statutory language is open-textured and Congress seems not to have deliberated about a specific issue, the Court ought to

203. Justice Brennan's opinion concurring in the judgment briefly alluded to cases in which lower courts had found slavelike conditions that resulted from psychological coercion. See id. at 2767. 
follow decisive evolutive considerations. This, indeed, is what statutory interpretation is ultimately all about-the case-by-case evolution of the statute to meet new problems and societal circumstances, and to meet new understandings of those problems and circumstances. The history that should drive statutory interpretation is not just the original expectations surrounding the statute, but also the ongoing historical development of the statute as those historical expectations and policies are applied in new and unanticipated factual settings.

\section{Practical Reasoning in Statutory Interpretation: Working Beyond the Counter-Majoritarian Anxiety}

Many of the criticisms we have raised in this part of the article relate to the style of the Supreme Court's decisions-namely, their one-sidedness and their reluctance to credit persuasive evolutive considerations. Several commentators attribute these weaknesses to the fact that law clerks and not the Justices actually draft many opinions. ${ }^{204}$ Thus even if the Justices actually decide cases by what we call "practical reasoning," it may be difficult to translate that reasoning into a written opinion, particularly for less experienced third persons such as law clerks. ${ }^{205}$

A deeper and more troubling reason why the Court's opinions often fail to reflect the actual weighing of interpretive factors is the Court's reluctance to admit that it-and not the Congress-makes the decision about statutory meaning in a difficult case. This "counter-majoritarian anxiety" arises from the view that statutory law derives its legitimacy from its enactment by Congress, which is elected by and accountable to the people. Hence, when the Court interprets statutes, it must somehow link its interpretation with the expectations of the democratically elected body. The Court does this by relying upon "objective" evidence that ties its interpretation to the text of the statute, the original expectations of Congress, or both. Indeed, the Court sometimes makes quite a show of preventing its "subjective" preferences from influencing statutory interpretation. ${ }^{206}$

204. See R. Posner, Federal Courts, supra note 13, at 102-29; Joseph Vining, Justice, Bureaucracy, and Legal Method, 80 Mich. L. Rev. 248, 251-52 (1981).

205. It is by now perhaps a cliché that law schools typically teach budding law clerks little that is useful about statutory interpretation. See, e.g., R. Posner, Federal CourTs, supra note 13 , at $336-40$.

206. Typical rhetoric by the Court emphasizes that it will only make law "interstitially," where Congress has not "clearly" acted. "Judicial perception that a particular result would be unreasonable may enter into the construction of ambiguous provisions, but cannot justify disregard of what Congress has plainly and intentionally provided." Commissioner v. Asphalt Prods. Co., 482 U.S. 117, 121 (1987) (per curiam). Though the Court hides behind this sort of rhetoric, its opinions-by both conservatives and liberals-routinely violate it. For the 1986 and 1987 Terms alone, see, e.g., Boyle v. United Technologies Corp., 108 S. Ct. 2510 (1988) (Scalia, J.); id. at 2519 (Brennan, J., dissenting); id. at 2528 (Stevens, J., dissenting); EEOC v. Commercial Office Prods. Co., 108 S. Ct. 1666 (1988) (Marshall, J.); id. at 1677 (Stevens, J., dissenting); United States Dep't of Justice v. Julian, 108 S. Ct. 1606 (1988) (Rehn- 
The Court's anxiety over its creative lawmaking role has often drawn cynical responses. The legal realists, for example, felt the Court was playing a clever game of three-card monte with Congress and the public, masking its lawmaking decisions behind the screen of neutral principles and determinate texts. ${ }^{207}$ Our assumptions are substantially less cynical. We believe that the Court feels torn by this countermajoritarian anxiety. The Justices realize that the hard cases are difficult and must often be resolved by consulting evolutive considerations, but they are reluctant to admit openly that they are making judgment calls that bear an uncertain relation to legislative texts and intentions. Such judgment calls, especially when based upon debatable evidence, current concerns, and judicially created policies, seem "subjective," and smack of judicial policymaking that displaces majoritarian government. To avoid the charge of subjectivity, the Justices feel a strong pull toward justifying their decisions by reference to "objective" evidencetext, legislative intentions, even statutory purposes-that is the evident product of majoritarian preferences. ${ }^{208}$

This analysis suggests that the appeal of foundationalism is deep indeed, for the leading foundationalist theories-textualism, intentionalism, and purposivism-are means by which the Court can seemingly reassure itself and the body politic that its statutory interpretation decisions represent an "objectively" apparent loyalty to democratic values, and not the Court's "subjective" preferences or value judgments. As we have seen, this reassurance is false, for several reasons. First, the link between foundationalist theories of interpretation and majoritarian political preference is tenuous, because the assumptions linking each method to majoritarianism are questionable. Second, the indeterminacy of each of those theories in the hard cases suggests that none of the theories can by itself "objectively" predict what a reasonable Court will do. And the indeterminacy of each theory subverts its claim to constrain the Court; as Weber suggests, the same Justices can look at the same textual and historical evidence and come up with vastly different interpretations of the statute. Third, none of the traditional theories can convincingly exclude evolutive factors from influencing decisions. Especially where the evolutive evidence is derived from more recent congressional action on related subjects-in Bob Jones, for example, the influence of modern civil rights legislation on tax preferences for segre-

quist, C.J.); id. at 1614 (Scalia, J., dissenting); United States v. Wells Fargo Bank, 485 U.S. 351 (1988) (Brennan, J.); Kelly v. Robinson, 479 U.S. 36 (1986) (Powell, J.); id. at 53 (Marshall, J., dissenting).

207. See K.N. Llewellyn, The Constitution as an Institution, 34 Colum. L. Rev. 1 (1934). "Three-card monte, like the shell-game, depends on the undoubted fact that the practiced hand is quicker than the unpracticed eye. A major technique is the diversion of attention .... I have elsewhere expressed my belief that until the prevailing theory of case-law is reformed, judicial card sharping is the part of wisdom, decency, and duty." Id. at 17 n.29.

208. A classic statement of this anxiety in constitutional lawmaking is Robert H. Bork, Neutral Principles and Some First Amendment Problems, 47 IND. L.J. 1 (1971). 
gated schools-legislative supremacy does not require the Court to ignore evolutive considerations in its decisions.

Pragmatism and hermeneutics have inspired our criticisms of statutory foundationalism. They also suggest therapies for the countermajoritarian anxiety. At the most general level, one insight of these philosophical theories is that the quest for objective foundations of knowledge is illusory, and that the failure of that quest does not consign us to nihilism or ad hoc relativism. As Richard Bernstein has put it, the goal of much modern thought is to take us "beyond objectivism and relativism." 209 Thus, he argues that the foundationalist urge in philosophy, though understandable, is the product of a longstanding thirst for philosophical certainty that is illusory. Earlier science, philosophy, and social science shared the belief that we can make progress only by identifying the correct foundationalist method and carefully applying its precepts. In each of these disciplines, the foundationalist faith has been shattered in this century by thinkers who have demonstrated the situatedness and historical particularity of much accepted foundational theory. ${ }^{210}$ Much as we traced the epistemological difficulties with the leading foundationalist theories of statutory interpretation, scientists and philosophers have criticized the foundationalist urge in their disciplines. The apparent failure of foundationalism ${ }^{211}$ has led some to embrace simple relativism or nihilism. This too has not been satisfactory. And whatever the problems of relativism in science or philosophy, they are even more troubling in legal theory, where, because of the clear link between law and political power, arbitrariness is most to be feared. ${ }^{212}$

The slide into relativism, however, is not a necessary consequence of rejecting foundationalism. A second lesson of modern pragmatism is that the opposition between objectivism and relativism is false. To deny that there is any single objective grounding for knowledge is not necessarily to assert that knowledge is impossible or purely relative; a middle position in the debate questions the tendency of both objectivists and relativists to assume that "real" knowledge, if it exists, must rest on unquestionable foundations. In philosophy, modern pragmatists argue that the paradigm for rationality is no longer that of

209. See R. Bernstein, Beyond Objectivism, supra note 8; R. Bernstein, Philosophical Profiles, supra note 8; see also R. RoRTY, supra note 2; R. RORTY, supra note 7.

210. Leading works include H. Gadamer. Truth and METhod, supra note 5 (philosophy); Thomas S. Kuhn, The Structure of Scientific Revolutions (2d ed. 1970) (science); Peter Winch, The Idea of a Social. Science (1958) (social science). These works and their implications are discussed in R. BERNSTEIN, BEYOND OBJECTIVISM, supra note 8, at 30-44.

211. The critique of foundationalism by works cited in note 210 supra is, of course, not universally accepted. Many philosophers, particularly in English-speaking countries, still operate under more or less foundationalist assumptions.

212. "[T]he desire for a theory of knowledge is a desire for constraint-a desire to find 'foundations' to which one might cling, frameworks beyond which one must not stray, objects which impose themselves, representations which cannot be gainsaid." R. RoRTY, supra note 2, at 315 . 
the isolated thinker rigorously proceeding by the one true method from unquestionable premises, but instead is intersubjective. As interlocutors seeking to reach agreement on an interpretation, we discuss the text from various perspectives, employ analogies and arguments, and self-consciously confront the limits of our own perspective. Over time the hermeneutical discourse develops traditions that constrain the sorts of arguments that can be made, and new discourses build upon the agreements reached in prior discourses. The interlocutors do not claim that what they decide is "true" in any foundational sense, but they do seek agreement that is useful, or workable, or satisfies whatever other practical criteria seem applicable. ${ }^{213}$

This debate in modern philosophy, therefore, is explicitly connected to the legal question: What is the nature of interpretation? ${ }^{214}$ An important lesson that hermeneutics suggests for lawyers is that statutory interpretation is not simply a matter of retrieving the original meaning from a historical text. Rather, the interpreter inevitably understands the text from her own historical perspective, and must take account of the relation between legal text and social circumstances. Gadamer's "fusing of horizons" metaphor captures this process: The historical text speaks to the present-day interpreter, who learns from the text and responds to it. The interpretation is the common ground reached in this interaction-a common ground that did not preexist the interaction. Gadamer denies, therefore, that the text has a predetermined meaning, because meaning comes only through this application of the text-for our purposes, a statute-to a particular situation-the case.

Thus, when Congress enacts a statute and empowers an agency, the courts, or both to "interpret" the statute, it sends its historically situated text off on a dynamic enterprise. There is no way around that. If Congress wants to minimize judicial evolution of its statutes, it has many strategies at its disposal: writing detailed statutes and amending them frequently; "sunsetting," or providing expiration dates for statutes; or delegating issues to an agency Congress thinks it can control. These strategies are reasonable, but so is the strategy of leaving difficult interpretive issues to judicial development over time. Contrary to foundationalist ideology, most political participants and observers both realize that judicial interpretations of statutes cannot be rigorously defended under majoritarian assumptions and are not troubled by this

213. For a related effort to deflate the apparent dichotomy between objectivism and relativism in constitutional adjudication, see Farber \& Frickey, Practical Reason, supra note 3, at $1652-56$.

214. Indeed, Gadamer approaches philosophy from a distinctly interpretivist perspective and takes judicial interpretation of statutes as the paradigm of interpretation generally. See H. Gadamer, Truth and Method, supra note 5, at 88-104; see also R. Bernstein, BeYond OBJECTIVISM, supra note 8. 
fact, probably because Congress is considerably more pragmatic than some of the legal scholars who comment on its work.

Hermeneutics offers one final, reassuring lesson for statutory interpretation. Although interpretation is neither objective nor predictable, it is bounded. Unlike the elected Congress, nonelected Justices are tightly constrained if hermeneutics is right about the nature of interpretation. The historical text itself constrains, for the interpreter is charged with learning from the text and working from it to the current problem. Moreover, the interpreter's perspective itself is conditioned by tradition-the evolution of the historical text as it has been interpreted, the values of society, and current circumstances. While these constraints certainly do not dictate a result, the interpreter cannot disregard the force of that which envelops and situates her in present society. Thus, the hermeneutical attitude charges the interpreter with a moral duty to give herself over to the dialogue, the to and fro play, with the historical text; to learn from the text, respond to the text, and reach common ground with the text. Whatever this may be, it is nothing so banal as subjectivism, nor is it so illusory as objectivism.

Consider these hermeneutical constraints in practice. In the easy cases, where the text, its history, and subsequent evolution speak in pretty much one direction, interpreters from a wide range of backgrounds and values can agree on an interpretation, as the Court did in Griffin. This agreement can also come in harder cases, such as Holy Trinity Church, where the interpreter must work beyond the apparent plain meaning of the text. Even in the hardest cases, it is striking how much common ground differently situated interpreters can find, if they genuinely throw themselves into the interpretive process.

Recall Kozminski, in which the Court seemed to splinter over the meaning of "involuntary servitude." Even in that case, the Court was unanimous that the convictions had to be vacated, because all nine Justices agreed that the instructions on psychological coercion were too broad. And all nine Justices believed that on retrial the victims' psychological vulnerability would be highly relevant to the jury's consideration. Although we agree with the specially concurring Justices that greater latitude should have been given to psychological evidence, we do not consider the Court's position to be so distant from our own. Indeed, the Court's opinion makes a considerable effort to acknowledge our concerns. That such a heterogenous Court could reach agreement on so much in Kozminski is itself noteworthy, and we believe that this is due to the practical reasoning and dialectical process in which all the opinions engaged in this instance.

The Court has been more truly fractured in the Weber line of cases, and a significant minority thinks Weber should be overruled. Here the different perspectives of the Justices make a considerable difference, and it may be that the high public visibility of the issue draws the inter- 
preters away from their hermeneutical enterprise. This does not trouble us, because the Weber issue is one on which a single discussion is not going to suggest conclusive answers. Instead, the Weber issue will remain with the Court over time, and the continuing stream of affirmative action cases will test the strength of the practical reasoning in that case. Our hunch is that for the time being affirmative action in the workplace is workable, but in the 1990 s will be subjected to greater limitations than those imposed by Weber. After that, affirmative action may be less necessary (if it has worked) or may be reconsidered (if it hasn't).

\section{ConCLusion}

Considering our critical tone throughout this article, it may seem surprising that we are ending on a somewhat optimistic note. We do believe that the Court's approach to resolving issues of statutory interpretation is largely grounded in practical reasoning, and thus that the Court's technique is consistent with other twentieth century trends, such as pragmatism. To be sure, the Court could substantially improve its performance if it more candidly reflected this reasoning process in its opinions. The Court ought to acknowledge that, standing alone, textualist and archeological approaches to statutory interpretation are overly simplistic techniques that provide only a chimera of the legitimacy the Court seeks. In contrast, by bringing all the relevant factors and all of our problem-solving skills to bear on difficult questions of statutory meaning in concrete situations, practical reasoning legitimates statutory interpretation through deliberation and candor. The legitimation is by no means ironclad, and in particular instances even sensitive efforts in practical reasoning may misfire, as in Kozminski. But, as in Kozminski, a candid explication of the reasoning process promises to narrow and highlight the elements in dispute and fosters a deliberative dialogue about statutory meaning in a concrete circumstance.

In the last analysis, statutory interpretation is neither mechanical foundationalism nor unbounded, unpredictable, and unprincipled decisionmaking. It is, therefore, fundamentally similar to judicial lawmaking in the areas of constitutional law and common law. In each area of judicial decisionmaking, deliberation and candor are necessary but not sufficient conditions for legitimating outcomes. For, as Richard Bernstein has noted, practical reasoning "presuppose[s] the existence of a sense of community and solidarity." 115 Even many of those who agree with us that dialogical practical reason might perform a substantial legitimating role may question whether there is an American legal interpretive community in which such a communal dialogue may flourish, or whether the interpretive community should be limited to the legal com-

215. R. Bernstein, Beyond OBJECTivism, supra note 8 , at 230. 
munity. ${ }^{216}$ We find much to commend about this point of view, and our descriptive model offers a framework for making this criticism. That is, if statutory interpretation is a fusion of horizons-those of the past text and the present interpreter-it makes a difference who the interpreter is. If judges are inevitably making political choices, their own political preunderstandings will make a difference in at least some cases, especially those where there is no political consensus.

One answer to this challenge that hermeneutics and modern pragmatism suggest is the potentially reconstructive nature of interpretation. ${ }^{217}$ Even without apparent consensus in society or in the legal community, the interpreter can often create some kind of agreement in the context of the narrow case, and through the case enlighten attitudes in the larger community. While we disagree with the results the Supreme Court has reached in a range of cases (such as Kozminski and $M c N a l l y)$, we have usually been impressed with the ability of most Justices to rise above their personal prejudgments. Legislative history, precedent, reasoned commentary, and other constraining factors do not completely close off avenues of judicial discretion, but the Justices do seem to learn from those links between past and present and often are able to apply those lessons to solve concrete cases in narrow, practical ways. In turn, these decisions teach the legal interpretive community something about the dynamic nature of statutes and the process of interpretation itself. That the dialogue between Court and community is imperfect is not so much a reason to reject the dialogic enterprise as it is to describe its shortcomings and expand its possibilities.

216. For a forceful argument that the necessary community does not exist, see MARK Tushnet, Red, White, \& Blue: A Critical Analysis of Constitutional Law 63-64 (1988). For a thoughtful analysis and rejoinder, see Suzanna Sherry, Oullaw Blues, 87 MiCH. L. REv. $1418,1428-37$ (1989) (reviewing M. TUSHNET, supra).

217. See Richard J. Bernstein, From Hermeneulics lo Praxis, in Hermeneutics and Praxis 273, 287-90 (R. Hollinger ed. 1985). 